\title{
The Consequences of Entrepreneurial Firm Founding on Innovation
}

\author{
Michael Ewens and Christian Fons-Rosen* \\ Preliminary, please do not cite
}

May 2013

\begin{abstract}
How does the innovative activity of an inventor at an entrepreneurial and established firm differ? With data on entrepreneurial firm founder mobility and patenting, we compare their inventions to a select set of inventors with whom they have strong co-inventor and co-worker connections. Founders and past co-inventors have very similar pre-trends in major patent variables. Five years after founding, difference-in-difference estimates show that the entrepreneurial founder continues to work on similar technology classes albeit with an increased focus on a smaller subset. Under this new innovation strategy, the founder produces $30 \%$ more patents that are of higher quality and more likely to be commercialized. The founder's post-exit patents cite pre-exit patents at a relatively higher rate, demonstrating close connections between the entrepreneurial and established firm. Comparing founders in hot and cold startup markets reveals no difference in results, suggesting the changes are unique to the high-growth entrepreneurial firm rather than quality ideas simply leaving established firms.
\end{abstract}

\footnotetext{
*Ewens: Carnegie Mellon University, mewens@cmu.edu. Fons-Rosen: Universitat Pompeu Fabra and Barcelona GSE, christian.fons-rosen@upf.edu. We thank Ajay Agrawal, Lee Branstetter, Steven Klepper, Matthew RhodesKropf, Antoinette Schoar and seminar participants at the SET Change Seminar (CMU) and MIT TIES Group for their comments. We also thank Correlation Ventures and Dow Jones VentureSource for access to the data. Gurinder Kaur provided valuable research assistance. All errors are our own.
} 
The entrepreneurial firm backed by venture capital (VC) is promoted as an important source of radical innovation. It is argued that such firms fill a gap that established firms innovative activity cannot or will not replicate. There are often strong connections between these two types of firms through the movement of employee to entrepreneurial firm founder. Existing theories of such exits and founding focus on their determinants: "rejected ideas" based on a friction at the established firm or employee learning. ${ }^{1}$ Empirical challenges have thus far limited analysis of the consequences of these exits and the unique characteristics of entrepreneurial firm innovation. This study uses the mobility of entrepreneurial firm founders from established firms to investigate innovations done just outside the established firm.

Any attempt to compare startup innovation to that of established firms using firm-level data faces several empirical challenges. The startups we observe are non-random as they are a selected set of all firms which typically outperform other new firms. ${ }^{2}$ Next, employee composition differs substantially across types of firms. It is thus difficult to disentangle whether firm-level results are driven by selection of individuals into firms or rather by firm-level characteristics like regulation or management practices. A within-firm analysis can avoid these issues; however, one would need pre-founding data for startups which is obviously non-existent. Fortunately, most theories of new firm formation through spinoffs put the firm's founder at the center of the model.

Analysis of individual-level patenting overcomes some of the empirical challenges as we can track patenting before and after firm founding. However, two new identification concerns arise. First, employees who decide to found a startup company are not a random sample of a firm's employees. Second, the timing of exit depends on expectations of future success or poor performance at the established firm. Several models and empirical studies of spinoffs (e.g. Klepper and Sleeper (2005)) show that anticipated or realized changes at the parent or industry impact exit rates. Such trends would bias even a standard fixed effects specification.

To overcome these two issues, we want to observe the startup founder's patenting activity in the absence of the startup founding. Employment histories and inventor-level patenting data for both

\footnotetext{
${ }^{1}$ Klepper and Sleeper (2005) summarize the empirical literature on spinoff formation: "[S]pinoffs pursue ideas involving new niche markets or technologies their parents are unwilling or slow to pursue." (pp. 1293)

${ }^{2}$ See Klepper and Thompson (2010).
} 
founders and non-founders in a given firm provides a potential solution to the first issue. Firm-level shocks can help alleviate concerns about certain forms of endogenous exit timing.

Consider a researcher working at an R\&D lab at IBM. She has a long patenting history, which includes many patents co-written with co-workers. She exits IBM to start a new firm and continues to patent. Her past co-workers remain at the IBM lab and continue research. This collection of inventors forms the base of our counter-factual sample and provides a plausible path of innovation the founder would have taken had she remained at IBM. Finally, observables can aid in selecting the best matches on pre-trends of patent outcomes (detailed below). For any causality claims, we require that the matched past co-workers who remain at the established firm and continue to patent form a valid counterfactual for the founders.

We build a database of founder employment histories, innovation activity and patent coinventors that uses a combination of several large datasets. We first identify the founders of the over 21,000 entrepreneurial firms in the venture capital database VentureSource. ${ }^{3}$ Next, this information is merged with the inventor-level patent data of Lai et al. (2011) using the entrepreneurial founder's employment history. Our identification strategy requires estimating changes around the founding event. We therefore measure patent outcomes four years prior and five years after the entrepreneurial firm founding. Additionally, we require patent activity and co-inventorship in the pre-founding period. These restrictions narrow the sample of founders to 2,337 founders with at least one patent (with a co-inventor at the same firm) in the four year period prior to the startup event. Next, we find a set of matches for a difference-in-difference specification.

Within the pool of pre-founding co-inventor/co-workers, we select our comparison group to best represent what would have occurred had the founder stayed. These inventors must remain at the firm and continue to patent. ${ }^{4}$ The goal is to find past co-inventors and co-workers with similar pre-trends in patenting rate, citations made characteristics, age of patent portfolio and citations received quality as the founder. Using a standard distance metric matching procedure (see Imbens (2004)), we compute the distance between each potential match and the founder

\footnotetext{
${ }^{3}$ Gompers, Lerner and Scharfstein (2005) use the same data that covered 1987 - 1999 to ask what characteristics of firms explain the exit of employees to startups.

${ }^{4}$ The results are unchanged if we allow matched controls to move to another firm that is not the entrepreneurial firm, however, this setting is not our ideal counter-factual.
} 
(within the same firm and co-inventor network). The final sample has 9-year patenting histories for 903 entrepreneurial founders and 3,067 matched controls. Importantly, the standard matching diagnostics - tests of pre-treatment variables and visual pre-trend analysis - are each satisfied, while the difference-in-difference specification mitigates many of the matching biases issues in such estimators (see Heckman et al. (1998)). ${ }^{5}$

After firm founding, founders must choose the industry or industries for patenting. They could pursue new ideas in an industry separate from the established firm. Here, the innovations are unlikely to have been produced in the established firm. Alternatively, the founder could remain in her known industry and thus, those of her past firm. An absence of change implies the established firm could have produced the innovation internally. To address these issues, we estimate a differencein-differences model with a founder-co-inventor cohort fixed effect. All results are therefore relative to the control group. Founders are $60 \%$ more likely to decrease their patenting in a known patent class and no more likely to enter a new class. Thus, startup founders in our sample focus their patenting in fewer patent classes in the startup. Our results are not driven by the strength in a state's covenant to not compete laws that are known to limit inventors' ability to start new firms (see Marx, Strumsky and Fleming (2009)). Next, we ask what additional patenting characteristics change after the startup event.

The difference-in-difference estimates imply economically large differences between the innovative activity of the founder and her matched controls. The founder patents at a $30 \%$ higher rate, produces more original patents and is $45 \%$ more likely to apply for a "continuation-in-part" (a patent characteristic that signals commercialization). Their higher rate of self-citations made confirms that founders are more likely to narrow their innovation activity to smaller set of ideas after founding. Compared to their matched cohort co-inventors, founders post-startup patenting is more prolific, original and focused.

The final set of patent characteristics are forward-looking and reveal the external validity and quality of patents, while documenting how they are connected to past and future patents. Patents

\footnotetext{
${ }^{5}$ Intuitively, if matching bias is time-invariant, we difference it away. Also, Heckman, Ichimura and Todd (1997) and others found improved matching procedures on labor data when matches were constrained to within geography or other groupings.
} 
produced after the startup are more general and receive $9 \%$ more non-self citations five years after startup founding. ${ }^{6}$ Generality captures the breadth of cites received and proxies for the level of basic research. Startup founders have $24 \%$ more self-cites to their pre-startup patents than their past co-inventors. In sum, the actively patenting entrepreneurial firm founder produces higher quality patents that build strongly off of her past inventions at the established firm. These facts extend the results on knowledge transfer found in the hard disk drive industry (e.g. Agarwal et al. (2004)) to multiple industries and over a long time period. The estimates also provide rich detail about how any VC selection mechanisms manifest themselves in patent characteristics: how do the "innovative" startups differ from the "imitators" of Hellman and Puri (2000)?

Two explanations remain for the changes in innovation after startup and relative to stayers at the established firm. The startup event itself could have a "treatment" effect on innovative activity. Alternatively, the founders in our sample could have a new, high quality idea that they take to the startup or is rejected by the firm. Here, we are simply observing the consequences of a time-varying unobserved trend. We distinguish such trends by comparing the market environment at the time of founder exit: hot, cold and normal. A "hot" market is one where there is top quartile growth in the number of new firms financed in the startup's industry over the 20 year sample. A "cold" market is analogously defined for bottom quartile growth. As proposed by Nanda and RhodesKropf (forthcoming), we predict founders starting firms in the latter environment to face a higher threshold for exit and thus, have a higher quality idea (on average). We confirm that prior to exit, startup founders in hot and cold markets are observably different across a wide range of patent and firm characteristics. If our conclusions are driven by high quality ideas leaving the firm, then conditioning on the state of the startup market should eliminate differences between the founder and past co-inventors. A triple-difference modification of the main empirical model exhibits little change and provides evidence for a startup treatment effect.

Further investigation rules out some alternative explanations: the exit of the founder could negatively impact her past co-inventors. ${ }^{7}$ In a sub-sample analysis, we recreate the matched sample

\footnotetext{
${ }^{6}$ The results on citations are consistent with Gonzalez-Uribe (2012), however, we ask how the startup event correlates with changes in citations rather than the VC financing.

${ }^{7}$ See Azoulay, Zivin and Wang (2010) for an example in medical publishing.
} 
by re-sorting the best matches by those that have the least pre-startup interactions with the founder. For example, a past co-inventor may have only written two of her 10 patents with the founder and is thus unlikely to be impacted by the exit. The main results are unchanged with this alternative matching distance criterion. We conclude that the estimates are not driven by a patent version of "superstar extinction."

Next we address some endogenous exit timing concerns. Research shows higher intra-industry spinoff rates around the time of acquisitions and CEO changes. ${ }^{8}$ For example, the founder could anticipate worse innovation success after a CEO replacement and leave to maintain her innovative output. We consider a set of founders exits that do not occur within a year of an acquisition or CEO change. If the previous results could be explained by these lifecycle effects, this sub-sample should have weaker estimates. The results are unchanged for all backward-looking measures, while only the generality differences are weaker. Last, we rule out whether the estimates could have happened by chance with a standard matching falsification test that reassigns founders as non-founders.

We have thus far ignored the venture capitalist. For our sample of firms, their first financing event occurs 2.1 years after founding. Centering the diff-in-diff event time around the first VC financing rather than the founding year significantly weakens the results, suggesting that much of the differences occur pre-VC. Similarly, some $65 \%$ of the founder's patent applications occur before the average VC financing. These facts provide support for a signaling story as studied in Hsu and Ziedonis (2007).

The startup founder, while connected to the past innovations at her previous employer, produces more patents that are of higher quality across several dimensions. Such facts are new to the literature on entrepreneurial firm formation and venture capital through the across-industry and time sample and the detailed innovation histories of founders. Importantly, our diff-in-diff strategy rules out an explanation based on the founder's time-invariant higher quality. Rather than generate radical innovations in young industries that are distinct from established firms, the entrepreneurs in our sample write impactful patents closely tied to the established firm. Those patents are associated with more fundamental research that exploits a diverse set of fields. We rule out a

\footnotetext{
${ }^{8}$ See Klepper (2009) for a survey and Eriksson and Moritz Kuhn (2006) for an example using Danish firms.
} 
negative externality of exit or exit prior to negative shocks at the established firm. We believe the features unique to the founder - generality, originality and focus - potentially characterize the typical "rejected idea" and point to additional research on how such characteristics relate to differences in organizational form, size, ownership structure and financing.

The results contribute to a literature on new firms and spinoffs. Gompers, Lerner and Scharfstein (2005) take similar employment histories of entrepreneurial firm executives and show a strong predictor of exit at an established firm was previous VC-backing. Their evidence that startups differ in patent classes from parents relates to our evidence on patent focus for founders. We extend their work by studying the ex-post differences in individual-level innovation around employee exits rather than their antecedents. Our empirical analysis reveals significant differences in patent output with close connections through citations, providing support for the model of Cassiman and Ueda (2006). ${ }^{9}$ Singh and Agrawal (2011) also study mobility in the patent data with a focus on movement between existing firms, while Chatterji (2008) studies similar movement in the medical device industry. Our study differs with a focus on new firm formation and inventor-level patent portfolio changes. The observed knowledge diffusion occurs between the founder and her pre-startup patent stock.

The paper also contributes to the literature on the role of venture capital in innovation. Hellman and Puri (2000) find that venture capitalists select more innovative firms (i.e. products in untested markets) and help those firms move to market quickly. Our founder to employee estimation reveals how these innovative firms distinguish themselves. Kortum and Lerner (2000) study the causal effect of $\mathrm{VC}$ financing on patenting rates and find increases in patenting after a random shock to the supply of VC. The current paper provides a lens on the micro-level relationship between VC and innovation and details how the innovation differs from other firms. The changes in innovation around founding are consistent with the Bernstein (2012) study of firm-level innovation and IPOs. Whereas this switch from private to public firm negatively effects innovation, the analysis of established to private (i.e. entrepreneurial firm) here finds the converse. Last, our empirical strategy extends that of Lerner, Sorensen and Strömberg (2011) who study the change in patenting around leveraged

\footnotetext{
${ }^{9}$ Other theories that provide a rational explanation for exits of quality innovation from firms include Hellmann (2007) and Klepper and Thompson (2010).
} 
buyouts. We investigate new firm formation in the venture capital market, while our identification strategy highlights new features about innovative activity in another part of private equity.

\section{$1 \quad$ Firm founding and innovation}

How should innovative activity differ between the established firm and startup? The literature on venture capital suggests it has an important role in innovation. VC and the firms they back patent more (e.g. Kortum and Lerner (2000)), have higher productivity (Chemmanur, Krishnan and Nandy (2011) and Puri and Zarutskie (forthcoming)), receive more citations (Gonzalez-Uribe (2012) and Kortum and Lerner (2000) ) and produce new services and products ( Hellman and Puri (2000)). In their survey of the literature, Da Rin, Hellmann and Puri (2011) conclude "the body of empirical evidence is consistent with the notion that VCs select more innovative companies, and then help them with the commercialization process" (pp 94). Overall, the evidence suggests that any comparison we conduct of entrepreneurial firms backed by VCs and established firms will show the former producing a higher quantity and quality of patents. Such a difference does not address whether the innovations produced by these firms could not have otherwise come from established firms. Identification of the patent characteristics that distinguish the two firm types is empirically challenging but can reveal what makes an idea a poor fit for an established firm and the benefits of the entrepreneurial firm as an organizational form. Our use of movement from employee to founder provides additional predictions.

Approximately $30 \%$ of the entrepreneurial firms backed by VC in our sample (see Section 2 below) were founded by individuals who have patents from their previous employment at established firms. The pool of established firms from which these founders leave is large (see Table 1). In a survey of the empirical literature on spinoffs, their parents and outcomes, Klepper (2009) concludes that most spinoffs produce products and work on ideas closely related to the parent firm. Models of this type of firm formation assume the established firm optimally rejects the founder's idea. An alternative class of models posits a learning process where employees gain market and entrepreneurial knowledge, eventually leaving to start new firms. ${ }^{10}$ Uncovering changes in patenting around these

\footnotetext{
${ }^{10}$ These two frameworks are similar to the "Xerox" and "Fairchild" hypotheses in Gompers, Lerner and Scharfstein
} 
events is the first step towards understanding the frictions that result in innovation production outside the established firm. The models do not provide direct predictions about patent characteristics of rejected ideas or entrepreneurial learning. Thus, we initially perform an exploratory analysis of a large set of patent outcomes and address how the collection of evidence fits with these economic models.

\section{Data}

Our goal is to document the employment and patenting histories of all entrepreneurial founders backed by venture capital in the U.S. We start with the VentureSource dataset of venture capital financings, entrepreneurs and investors. This database covers all U.S. venture capital financings and the entrepreneurial firms that receive such capital from 1990 to the present. The important entrepreneurial firm characteristics for this study are founder(s), founding year, first venture capital financing and industry. We stop tracking founders and entrepreneurial firms were founded after 2007 so we have ample time to track the post-founding characteristics. ${ }^{11}$ Entrepreneurial firms also exit the sample when they have an initial public offering, are acquired or failed. This restrictions avoids comparing established firms to others of the same type after ownership changes.

We have the full management and founding team for over $80 \%$ of the 21,000 entrepreneurial firms in the full sample. From these, we first identify the founder using the firm's website, Capital IQ and web searches we identify 31,160 founders. ${ }^{12}$ The VentureSource data also provides an employment history of these newly identified founders as of the time they start the firm, which we take to the Lai et al. (2011) inventor-level database. ${ }^{13}$

Matching entrepreneurial founder to inventor of a particular patent requires several steps, greatly facilitated by (i) the employment histories and (ii) the unique inventor identifiers in Lai et al. (2011). A fuzzy string match of the unique past employers associated with founders and (2005).

${ }^{11}$ We filled in $55 \%$ of missing founding years with searches of both the California and Delaware secretary of state websites that list articles of incorporation information. Any remaining missing founding dates were assumed to be at the first VC financing event.

${ }^{12}$ Many of the firms have multiple founders.

${ }^{13}$ Many were missing, so another data collection exercise similar to the founder identification was required to find employment histories. 
company name on the patent application (i.e. assignee) retrieves the firm identifier from the patent data. ${ }^{14}$ This identifier in hand, the task of finding the founder's name in the inventor pool is simplified and more accurate. We focus the search for the person name to within the founder's full set of past employers. The weakest matches and all possible false negatives - 17,000 founders - were then hand-checked with Google Patent Search. ${ }^{15}$ Some $20 \%$ of founders have a patent, although many of these are single patents over a long career. When we focus on the years four years prior to the entrepreneurial firm founding, there are 2,337 founders with at least one patent.

The top pre-founding employers for all founders - with and without patents - are listed in Table $1 .{ }^{16}$ The largest source of new VC-backed entrepreneurial firms is IBM followed by many well-known firms in technology, biotech and communications. For these startups, some $48 \%$ founded in California, while Massachusetts and Texas account for $10 \%$ and $6 \%$ respectively. The time period of interest for each founder and her entrepreneurial firm is four years prior to five years after the founding year. ${ }^{17}$ We chose five years after as the average entrepreneurial firm in the VentureSource database exits without failure in approximately five years. The pre-startup period was chosen to balance the matching goals and any age issues with patent variables. The results are insensitive to a choice of five or three years prior to the founding.

\subsection{Patent variables}

The discussion in Section 1 suggests a diverse set of patent outcomes are of interest. We consider two standard classes of characteristics - "backward-looking" and "forward-looking" - that capture the types of patents produced and their quality. Many of these variables are commonly used in the innovation literature, while some are relatively new.

\footnotetext{
${ }^{14} \mathrm{~A}$ random set of 1000 of these matches were hand-checked manually using the more detailed founder biographies available on websites or in Capital IQ.

${ }^{15}$ An RA searched for the inventor's full name and the employer name. If they found a match, we saved available patent numbers and merged back with Lai et al. (2011). Confirmation of the merge was done using the year of entrepreneurial firm founding to remove false positives.

${ }^{16}$ This set of firms is a similar to those used in Gompers, Lerner and Scharfstein (2005), however, they study all managers of entrepreneurial firms who left publicly-held companies.

${ }^{17}$ Again, if the firm has an IPO or other exit this latter interval stops.
} 


\subsubsection{Backward-looking measures}

Backward-looking patent features document how a patent appears at the time of its application. We first calculate the patenting rate or the number of patents applied per year. Next, we calculate the biased-adjusted originality of the patents which measures the breadth of patent industry sub-classes cited by the patent. Originality proxies for the fundamental nature of the patent. A citation made by a patent can reference the inventor's work or a work outside of the her portfolio. We calculate the fraction of self-citations made for each patent as the ratio of total cites of the former type over total citations made. ${ }^{18}$ The rate of self citations are often used as a measure of innovation focus. Next, we create a measure of patent class age and commercialization.

The typical venture capital-backed firm commercializes products (e.g. Gans, Hsu and Stern (2002)). The patent data contains a type of filing called a "continuation-in-part" (CIP) that proxies for this activity. CIPs are often used to build off of an already patented idea that is still in the application process to stake claims to particular commercial uses of an invention. The variable "\% CIP" is the fraction of all patents that have this designation over a given time period. Last, we construct a measure of patent technology class age using the original patent classification system in the NBER data. ${ }^{19}$ For the major subclasses of the seven patent classes, the age measure is normalized to be zero when they first appear in the database and one at the end (2007). This normalization attempts to capture variation in the speed of a patent class' use seen in Figure 1.

\subsubsection{Forward-looking measures}

Forward-looking patent measures capture the impact of a patent after application. We use three popular patent outcomes: non-self citations received, generality and "importance forward." The count of non-self citations received is measured every year after patent application and summed across an inventor's patents. Most patents receive very few citations, while a few receive a large amount. To address any concerns that the mean is uninformative, we construct a dummy variable "Winner" that is one if the patent was in the top $10 \%$ of citations received of all patents applied for in the same year and patent class. Next, generality (biased-adjusted) summarizes the diversity

\footnotetext{
${ }^{18}$ This continuous variable mirrors the idea of an "external" or exploratory patent.

${ }^{19}$ The patent office often re-classifies existing patents to a new system, making simple patent age difficult.
} 
of patent sub-classes that cite the patent. Higher generality equates to higher impact as the patent receives cites by a wide range of fields. "Importance forward" is a variant of citations received variable that puts additional value on patents that themselves receive many cites. The last variable

- "Pre-startup self-citations received" - counts the number of self-citations received by the inventor's pre-exit patent stock. We collect all patents applied for in the time period four years prior to the entrepreneurial firm founding and then track the number of self-cites by those patents' authors in each subsequent year. The measure captures the connections between the post-founding patents and those at the established firm.

We now discuss how these patent variables will guide the search for control inventors.

\section{Counterfactual search}

Even with knowledge of the full patenting and employment histories of the entrepreneurial founder, we cannot easily address how innovative activity differs between startups and established firms. A within-founder analysis centered on the startup event lacks a benchmark or comparison group, particularly if the set of founders are unique. Fortunately, the co-inventorship and co-worker network in our merged dataset presents a solution. These connections invite an analysis of how the same inventor patents in two different firms. Our goal is to collect inventors that approximate what would have happened had the entrepreneurial founder remained at the firm.

For each of the 2,337 entrepreneurial founders, we select all co-inventors on patents associated with the last assignee that appears in their patent portfolio the year immediately prior to the founding event. Restricting our potential controls to this set alleviates many issues in matching estimators that have few observables available (see Heckman, Ichimura and Todd (1997)). The final difference-in-difference estimation requires that the "best matches" have parallel trends to that of the founder, so we include pre-trends of our variables of interest. Section 2.1 details ten patent outcomes, many of which are measured years after patent application. We narrow the set of match variables to patenting rate, generality, originality and citations received and calculate their growth rates with the terminal date set to the year prior to the founding event. The final matching procedure uses one year and two year rates. Additionally, we want to ensure that the founders and 
co-inventors are similar by age and speciality, so we include year they first appeared in the patent data and the share of patents in each patent class.

We follow the common approach in the matching literature and measure the Mahalonobis distance for each potential match. ${ }^{20}$ To select the best matches, we use a version of caliper matching, where the distance threshold is set by the mean of the full sample distances. That is, a potential match is kept if the distance between her and the founder is less than the average distance across all matches. Many inventors collaborate on patents that combine disparate skill sets. For example, a semiconductor is often a combination of software and hardware. Co-inventors on such patents are in fact quite dissimilar in their skill sets and choice of exit decision. Thus, our caliper threshold eliminates some patenting founders whose best matches are quite poor relative to the typical match. From the 1,659 founders with at least one patent before and after the startup, 532 lack quality matches based on these criteria. Finally, some matches stop patenting actively in the post-startup period, which leaves us with 903 founders with at least one matched co-inventor. We have a total of 3,067 non-founder inventors for an average of 3.1 matches per founder.

We can compare the set of entrepreneurial firms who founders lack a match to that of the full sample. Table 4 shows that the unmatched founders have firms founded earlier and somewhat mechanically, are more likely to have an IPO. Among the other observables, there are no large differences and thus we believe the final matched sample is representative of the set of active founder-inventors. Finally, in unreported results we compare the characteristics of founders that cease patenting at startup. Such founders have statistically fewer patents, start companies in the more recent past and have fewer citations received prior to startup. These founders are a interesting avenue for future research, particularly regarding if and how they build innovative teams rather than patent themselves.

\subsection{Diagnostics}

How well do the matches perform? Table 5 presents the means of the match inputs and other observables, where the mean is computed across all groups. As the means and standard errors

\footnotetext{
${ }^{20}$ This distance behaves like a Euclidean norm, but assigns weights to variables that are inverse to their variances. The results are insensitive to using the Abadie and Imbens (2006) distance metric.
} 
make clear, the samples are statistically similar in the pre-startup period (t-tests confirm this). Second, Figures 3 and 4 preview of our main empirical estimates and demonstrates the efficacy of the match. The estimates of the difference-in-difference interactions for the pre-startup founding are statistically zero (the excluded category is the year prior to startup). Plots for other variables are similar in a lack of pre-trends. The strong match on observables is encouraging and perhaps not surprising given our narrow focus within the co-inventorship and co-worker group. These matched founder-co-inventor groups (hereafter, cohorts) can now address our original questions.

\section{Estimation}

The main specification is a difference-in-difference estimator with a cohort fixed effect for each founder-matched co-inventor group. Let $P_{i l t}$ be one of the patent variables described in Section 2 where the event time is defined in the range $t \in[-4,5]$ :

$$
P_{i l t}=\gamma_{0}+\alpha_{l}+\text { Founder }_{i l}+\sum_{t=-4, t \neq-1}^{5} \beta_{t} T_{t}+\sum_{t=-4, t \neq-1}^{5} \rho_{t} \text { Founder }_{i l} T_{t}+\epsilon_{i l t}
$$

where $i$ indexes inventor and $l$ indexes cohort. ${ }^{21}$ The dummy Founder $_{i l}$ is one if inventor $i$ in cohort $l$ is the founder and $T_{t}$ are the event time dummies with $T_{-1}$ the excluded categories. If the founder differs from her matched co-inventors after startup, then we expect $\hat{\rho}_{s} \neq 0$ for $s \geq 0$.

Estimates from equation (1) provide a test of the parallel trends assumption of the matching algorithm. As discussed, patenting rate and pre-startup self-citations demonstrate a good prefounding match (Figures 3 and 4). Our main estimation uses a variant of (1) because disaggregation of patenting variables by year results in noisy estimates, while the long time series raises serial correlation issues (see Bertrand, Duflo and Mullainathan (2000)).

For each inventor, we calculate averages of the ten patent variables in two intervals. The first is four years prior to the firm founding $([-4,-1])$ and the second is the startup year up to five years after $([0,5])$. The averages are weighted by the number of patents applied in each year (if relevant).

\footnotetext{
${ }^{21} \mathrm{An}$ inventor $i$ may be matched with multiple founders $l$.
} 
The new estimation becomes:

$$
P_{i l t}=\beta_{0}+\alpha_{i l}+\beta_{1} * \text { After }_{l t}+\beta_{2} \text { Founder }_{i l}+\beta_{3} \text { Founder }_{i l} * \text { After }_{l t}+\epsilon_{i l t}
$$

where indices are as in (1), $t \in\{0,1\}$ for the pre- and post-founding periods and "After" is a dummy equal to one for the latter. The parameter of interest is $\beta_{3}$, which measures the difference between the founder and matched controls after the startup event. It is important to note the inclusion of the cohort fixed effect $\alpha_{i l}$. The fixed effect results in a within-cohort interpretation where $\hat{\beta}_{3}$ is the difference relative to the matched-co-inventor controls. Before estimating (2), we investigate the dynamics of the founder's choice of patent class.

\subsection{Changes in technology classes}

A startup founder can change the classes of patents in which she invents. ${ }^{22}$ Such changes can signal new requirements of producing innovation in startups versus established firms. Importantly, changes in industry focus of founders could confound any difference-in-difference estimates if industries are on different trends. For each inventor and patent class, let $D_{i l k}$ define whether the inventor decreased her patenting in class $k$ after the founding year:

$$
D_{i l k}= \begin{cases}1 & \text { if } f_{i l k 1}<f_{i l k 0} \text { where } f_{i l k 0}>0 \\ 0 & \text { if } f_{i l k 1} \geq f_{i k 0} \text { where } f_{i l k 0}>0\end{cases}
$$

where $f_{i l k t}$ if the fraction of inventor $i$ 's patents in cohort $l$ where the pre- $(t=0)$ or post-founding $(t=1)$ periods. We estimate a conditional logit model where the unit of observation is the inventor and patent class for all inventors with $f_{i k 0}>0$ :

$$
D_{i l k}=\beta_{0}+\beta_{1} \text { Founder }_{i l}+\beta_{2} X_{i l 0}+\alpha_{l}+\rho_{k}+\epsilon_{i l k} .
$$

\footnotetext{
${ }^{22}$ This analysis is similar to the comparison of parent and startup patent classes in Gompers, Lerner and Scharfstein (2005). We extend it by using founder-level data and the difference-in-difference specification.
} 
The indices are as in (1) and $\rho_{k}$ is a patent class fixed effect. The controls $X_{i l 0}$ include the share of patents in class $k$ in the pre-founding period and the change in total patents between the pre- and post-founding. If founders are more likely to decrease patent rates in the patent classes where they have experience, then $\hat{\beta}_{1}>0$. The coefficient's sign does not help us separate the focus strategy from one where they enter whole new patent classes. We thus construct a variable in the same spirit as (3) but captures whether an inventor shifts from zero patenting to positive patenting in class $k$. A positive difference in this regression combined with one in (4) implies a shift out of classes with experience and into new classes, while the opposite signals a narrowing of patent class focus.

\section{Results}

\subsection{Change in technology classes}

We first estimate the change in patent class industry regression (4) for both the decrease and increase outcomes. Table 6 presents the results. ${ }^{23}$ Each column reports the estimated odds ratios (exponentiated coefficients) of the conditional logit estimator of (4) where the fixed effect is the founder cohort and standard errors are clustered at the cohort level. An inventor has one observation for each patent class for which see has a pre-founding patent, so we also include patent class fixed effects.

Column 1 shows that compared to the match set of co-worker/authors, startup founders are more likely to shift out of one of their pre-startup patent classes. The odds ratio implies an approximately $60 \%$ higher likelihood of decreasing the rate of patenting in the patent class. Column (2) presents the estimates from a similar estimation where the dependent variable captures whether, poststartup, the inventor entered a patent class where they had no pre-startup experience. Founders are no more likely to shift to a patent class where they lack experience. Combined with the results in column (1), we conclude that founders are on average focusing their patenting in fewer classes relative to their cohort.

The founder's exit decision may depend on the strength of her state's covenant to not compete

\footnotetext{
${ }^{23}$ The patent classes are generally, "Biotech," "Chemicals," "Software," "Computer Networks," "Semiconductors," "Transportation" and "Mechanical Engineering."
} 
laws (see Marx, Strumsky and Fleming (2009)). That is, these laws' strength increase the likelihood a new firm starts in an industry that differs from the parent firm. Although the results go in the opposite direction of what such restrictions would predict, columns (3) and (4) repeat these regressions on the subset of states that have weak covenant to not compete laws (see Malsberger (2008) for the index). The robustness check illustrates these legal restrictions are not a first-order concern. Overall, we find no evidence of a shift to new industries, but rather a focus on patent classes that are connected to both the founder and established firm's past. Additional analysis of the other patent characteristics will help us understand the changes at founding.

\subsection{Within-founder}

Before estimating the full specification in (2), we consider a model ruled out as problematic above: within-founder. Although such a regression cannot address pre-trends before the startup event, the resulting estimates will provide a benchmark addressing the source of changes observed in the difference-in-difference estimates. For example, finding an insignificant change in the withinfounder analysis and a positive change relative to the cohort in the diff-in-diff is suggestive of a possible negative shock to the established firm around the startup event. Alternatively, the estimates between the two models - when the sign agrees - reveals any over- or under-estimate of coefficients. The within-founder estimator is:

$$
P_{i t}=\beta_{0}+\alpha_{i}+\beta_{1} * \text { After }_{i t}+\epsilon_{i l t}
$$

where $\alpha_{i}$ if the founder fixed effects and the sample includes all founders with one patent before and after the startup event. Table 7 presents the results for the five forward-looking and five backward-looking patent measures. Columns with "Poisson FE" present poisson fixed effect estimates. "FE" is the fixed effect model and "GLM FE" is the non-linear estimator for fractional dependent variables proposed by Papke and Wooldridge (2008). All estimators cluster the standard

errors at the unit of the fixed effect. Panel A suggests that founders have no change in patenting rate after startup, produce more general patents and move into relatively older patent classes. The last result could simply follow from the full set of patent classes getting older over time, which 
reveals another benefit of the diff-in-diff. Panel B shows no change in cites to pre-startup patents, while both generality and total non-self citations received increase significantly. Again, the cites received could follow from a underlying trend for all patent citations counts. We now move to the full specification using our match cohorts and diff-in-diff.

\subsection{Difference-in-difference}

Table 8 presents the estimates of (2) for the variables described in Section 2.1 and the estimators described for the within-founder analysis. Consider first the backward-looking estimates in Panel A and recall the inclusion of the cohort fixed effects implies the "Founder X Post" is the difference in the dependent variable between the founder and matched co-inventors for the five years after startup founding. ${ }^{24}$ The estimates show significant differences in backward-looking measures: startup founders patent more, produce more original patents, have a higher fraction of self-cites and more likely to patent commercially. Economically, the founders produce $30 \%$ more patents and are $41 \%$ more likely to cite any previous patent than their past co-workers. The latter result suggests an increased focus on a small set of ideas. Figures 2 and 3 show that any increases in patenting occur close to the startup event, however, any relative differences are likely a slowing or an already downward trend. The higher originality implies the founder moves towards more fundamental research.

The forward-looking measures in Panel $\mathrm{B}$ also demonstrate meaningful differences between founders and matched co-inventors. Startup founders produce patents that have $8 \%$ more non-self citations received and higher generality five years after the founding event. ${ }^{25}$ The higher citations received do not translate into a higher probability of a ground-breaking "winner" patent or higher importance forward. The startup founder appears to produce higher quality, more impactful patents across several patent measures. Finally, the post-startup patents of the founder are $27 \%$ more likely to cite a pre-startup patent written at the established firms, suggesting a strong connection between

\footnotetext{
${ }^{24}$ The matched cohort approach implies that we need not include year or industry effects as the cohort patents in the same time period and is matched by industry. Similarly, much of the within-year-industry scaling (e.g. Bernstein (2012)) is not necessary.

${ }^{25}$ Interpretation of interaction terms and their marginal effects can be misleading (see Ai and Norton (2003)), so the economic magnitudes for the poisson regressions reported are from implied incidence rate ratios that do not suffer from this problem.
} 
the work of the startup and the parent. In particular, if the control group describes the typical behavior of an inventor working on old ideas and discovering new inventions, then this difference implies a focus on specific pre-startup ideas commercialized in the startup.

Overall, there are stark differences in patenting by a founder and her former co-inventors and co-workers around the startup event. Could such patenting have been done at the established firm? We next exploit variation in founder and idea quality to isolate any possible treatment effects of the startup event.

\subsection{Variation in founder quality}

The estimates thus far rule out two major empirical concerns. First, the results cannot be explained by higher quality or ability of founders exiting the firm to form a new firm. Insofar as such characteristics are time-invariant, they are differenced out. Second, the matched set of co-inventor and co-worker ensures that underlying trends similar to both groups are the source of any changes in innovative activity. What's left? As with most diff-in-diff estimators, time-varying unobserved heterogeneity can bias estimates. Such an unobservable has a clear analogue in our setting through the notion of an "idea shock." Here, the founder comes upon a new idea that she either hides from her employer or the employer rejects unobservably. The subsequent founding of a VC-backed firm is therefore a consequence of a high quality idea leaving a firm, rather than a treatment effect of the startup founding on innovative activity.

Finding a clean instrument that is correlated with leaving the firm but is uncorrelated with an idea shock is challenging. Lacking a clear instrumental variable strategy employee exit, we use plausible heterogeneity in entrepreneurial firm founders to help isolate the magnitude of this endogeneity concern. Simply, we exploit differences in the average quality of ideas that lead to spinoffs over the venture capital investment cycle.

\section{Hot vs. cold startups}

Ideally, we would like to observe the quality of the unobserved idea that led to the entrepreneurial founders' exit. We propose instead a comparison of founders who exit in hot markets versus other 
parts of the market cycles as a way to address some of the endogeneity concerns. Nanda and Rhodes-Kropf (forthcoming) argue that the average idea is worse in hot times, but the set of such ideas that are funded are also more likely to be experimental or ground-breaking. In our setting, consider two founders. One exits her firm during a relatively slow period of VC funding of startups in her industry. The more difficult financing environment results in a higher threshold on idea and founder quality, so we would expect her "idea shock" to be relatively better. In contrast, employees exiting to start a new firm during hot markets when the number of financings and capital is high may be less likely to have very promising "idea shocks."

How does this sub-sample or comparison group address the endogeneity concern? We are attempting to isolate the treatment effect of the startup event on patenting activity, so we would like to control for the quality of the new idea (if that is the source of the exit). The next best solution is to find a real source of heterogeneity in such ideas, which we do through the exit timing. Startup founders who exit during cold markets likely have relatively better ideas and in turn are possibly the source of any observed innovation differences without a true treatment effect. Thus, if the current diff-in-diff estimate is simply quality ideas exiting the firm - rejected or "stolen" - a triple difference with cold market startups should explain much of the variation. Alternatively, if there is still a positive correlation between the startup event and innovation changes after exploiting variation across the sectoral business cycle, it is strong evidence for the idea shock as a first order concern. In other words, if the coefficient of our DD estimation is relatively consistent and stable across both types of periods (hot and cold), it would mean that our estimated impact does not depend on our proxies for quality of ideas. If that is so, it would support our claim that there is something more than an idea that leads to our results.

We define startups as in "hot" or "cold" markets depending on the characteristics of the VC market of their startups industry immediately prior to the startup event. For each of the 18 startup industry categories, we calculate the number of new firms financed by VC in each year. Each possible startup year - 1987 - 2008 - we sort the 1 and 2 year growth rates in this measure. A "cold" market is defined as a year with bottom quartile growth in new firms financed and a "hot" market is same growth measure, but in the top quartile. Figure 5 shows these indicators for two 
major industries: medical devices and semiconductors.

Next, the rationale discussed above suggests that startup founders who exit in cold times should be relatively better quality than those in other parts of the investment cycle. Table 12 shows that cold market founders are statistically different across several pre-startup patent measures: patenting rate, commercialization propensity and non-self citations received. This evidence is supportive of our hypothesis that cold markets produces relatively better startup founders. Furthermore, as expected there are significantly more startups formed in hot markets than cold: 319 versus 196. We now estimate the triple difference model:

$$
\begin{array}{r}
P_{i l t}=\beta_{0}+\alpha_{i l}+\beta_{1} * \operatorname{After}_{l t}+\beta_{2} \text { Founder }_{i l}+\beta_{3} \text { Founder }_{i l} * \operatorname{After}_{l t}+\beta_{4} \text { Coldmarket } * \text { After }+ \\
\beta_{5} \text { Founder } * \text { After }+\beta_{6} \text { Coldmarket } * \text { After } * \text { Founder }+\epsilon_{i l t}
\end{array}
$$

where "Cold market" is equal to one for startup years with below median growth in new entrepreneurial firms in the startup's industry. The dummy is defined for startups financing 1988 to 2008. To isolate the importance of this endogeneity concern, we use the sample of firms where there is no corporate change (e.g. CEO transition) as detailed in Section 7 below. We are left with 668 entrepreneurial firms (at most).

\section{Hot vs. cold results}

Table 13 presents the backward-looking patent measures, while Table 14 shows the estimates for the forward-looking measures. The two main coefficients of interest are the triple interaction "Cold market x Post x Founder" and the main interaction "Founder X Post." For Table 13, the main interaction coefficient remains statistically significant across the first four dependent variables. The coefficient on the triple interaction term is relatively smaller than (i.e. much closer to zero) these estimates and statistically insignificant. If the cold market founders can explain the major results in Table 10, then we would expect the triple interaction term to have the relatively larger coefficient. The estimates instead suggest that the post-startup changes in innovative activity do not primarily 
depend on VC market activity.

Table 14 presents the same triple-difference results for the forward-looking measures. Prestartup patent self-citations and generality and effectively unchanged, with the "Cold market $\mathrm{x}$ Post x Founder" coefficient statistically insignificant. Interestingly, the triple interaction coefficient is usually an order of magnitude closer to zero than the coefficient on "Founder X Post", thereby

implying that the lack of statistical significance of not mainly driven by a lack of power. The coefficient on the main interaction for "Non-self cites received" is no longer significant, however, this appears to be a power issue. The magnitude in Table 16 is equivalent to that of Table 8 (slightly larger), so it appears the splitting of the sample reduces sampling variation.

Overall, we conclude as above that the cold market founders are not driving the main conclusions of the paper. This evidence is suggestive of a real impact of the startup event on founder patenting, once we proxy for idea quality.

\section{Discussion}

It is perhaps unsurprising that venture capital-backed firms with active founder-inventors produce better patents than their past co-workers. Simply, it is well-accepted that the least that VCs do is select quality ideas. Despite this, we believe the evidence presented thus far is the first detailed look at how innovative activity between these firm types differs after addressing a fundamental concern about (i) selection of founders and (ii) exit following or causing negative trends. Such an analysis is not possible without the combination of employment mobility and a co-inventorship network of inventors. We can say something more about whether innovations at these startups are radically different. Given these firms have quality innovations, the differences can potentially highlight rejected ideas or those that employees prefer to own in their own firm.

The results in Panel B of Table 8 suggest the typical founder exploits knowledge patented at the established firm. The estimates in column 1 of Panel B imply that the pre-startup patent stock of the founder are $27 \%$ more likely to receive a cite from her post-startup patents. Simply, the startup founder is relatively more likely to use the ideas and inventions of her past employer. Radical ideas that are disjoint from the established firm would likely not behave in such a way. 
The last important feature of the founder is the higher rate of commercialization as proxied by a higher CIP rate. Overall, the evidence shows a set of high quality ideas closely connected to the established firms being intensely commercialized by a startup. Thus, the established firms in our sample appear to have passed on or missing a quality product.

A large class of models that explain employee exits and this kind of project rejection assume the manager is incapable of assessing the innovation's quality or the firm believes the resulting product would cannibalize other products. What do the other patent characteristics reveal about such rejections? Founders produce more original and general patents after founding. These characteristics signal a shift to more fundamental research post-founding. ${ }^{26}$ These two features of patents likely correlate with large, established firms product and innovation strategies. Last, the evidence from changes in industry and fraction of self-cites points to a narrowing of the founder's innovation on a particular idea. The patents observed just outside the firm may be too focused and require too basic of research for the established firm.

\section{Alternative explanations and robustness}

\section{Superstar extinction?}

The matching algorithm matches the pre-founding trends in the major patent variables. Figures 3 - 4 confirm it achieved this goal. However, the founding event and exit of the inventor could itself signal a change at the established firm that could explain the main difference-in-difference results. Simply, the founder may have timed her exit expecting a fall in her co-inventor patenting activity or her exit could have caused such a fall. The latter concern mimics the setting of Azoulay, Zivin and Wang (2010) who study the effects of unexpected deaths of star researchers in medical publishing on their co-authors.

To address this concern, we look at the pool of co-workers who are the least likely to be affected by the exit. Let $x$ be the fraction of a co-workers' patents in $[-4,-1]$ that were co-written with the founder. We take the distance metrics from the matching algorithm and re-scale them by $1-x$,

\footnotetext{
${ }^{26}$ Bernstein (2012) finds the inverse of these results at the firm-level when tracking innovation around the private to public change. Firms innovate with less original and general patents after going public.
} 
effectively shrinking the distance between the least connected co-inventors, while maintaining the benefits of the match distance. Table 11 demonstrates that the major estimates from Table 8 are unchanged using cohort. We conclude that the patent version of "superstar extinction" is not a major driver of our results. ${ }^{27}$

\section{Corporate change exits}

The exit of employee from established firm to new firms is often precipitated by major corporate changes. These include CEO transitions or acquisition events. ${ }^{28}$ The difference-in-difference estimates could be driven by a downward trend at the established firm in innovative activity rather than a positive change at the startup event. We address this concern by identifying all the assignees in the data that had a $\mathrm{CEO}$ change or a large M\&A transaction (target or acquirer) at least two years prior to the startup founding. ${ }^{29}$ We use the executive compensation data Execucomp that covers on public firms and SDC which covers the universe of most merger and acquisition activity. ${ }^{30}$ A large transaction is an acquisition with a reported value of at least $10 \%$ of the firm's market capitalization. $22 \%$ of the startup events in our sample occur after a CEO change or large M\&A transaction.

This robustness test assumes that founders who do not leave after major corporate change are less likely to be timing an exit before falling innovation. If the main results are driven by corporate change, this sub-sample should have weaker estimates than those of Table 8. The estimates in Table 9 shows that only the estimates of generality differ, while they coefficient remains positive. This result is suggestive that the exit of founders after a major corporate changes and any resulting impacts on firm innovation is not a concern.

\footnotetext{
${ }^{27}$ It is plausible that the founder hires away her past co-inventors after the startup founding and we are capturing this impact. However, our matching algorithm requires that the co-inventor remain at the past employer for the post-founding period. Thus, only if the founder depletes the entire talent pool do we think this will drive the results.

${ }^{28}$ Klepper (2009) reviews the empirical literature that demonstrates the positive correlation between these corporate changes and employee exits to new firms.

${ }^{29}$ Results are insensitive to using 1 year as a cutoff.

${ }^{30}$ If the established firm is private, we will not identify a CEO change. Only if the firm is public or is a private target firm, will be identify M\&A.
} 


\section{What about venture capital?}

The empirical analyses above uses the founding of the entrepreneurial firm as the event of interest rather than the first VC financing event. How much of the observed results can be explained by the venture capital financing? Preliminary analysis finds little evidence of a treatment effect. The average firm in our final sample received their first infusion of capital 2.1 years after founding. Figures 3 and 4 show that much of the relative differences occur immediately after the founding event. Similarly, the patenting rate and empirical cdf of Figure 2 demonstrate that $65 \%$ of the patent applications occur before the typical first VC financing. Thus, the results in Panel A are likely not driven by the VC financing. Re-estimating the model (2) with "After" replaced with "After VC" results in significantly insignificant estimates in Panel A and weaker estimates (with signs unchanged) in Panel B. Further work is required to estimate a full triple-difference that introduces an additional interaction term "After * Founder * After VC."

\section{Matching process}

Conditional on finding a match distance between a past co-worker and the founder, we consider only the set of all matches that are below the full sample mean distance. The results are insensitive to altering the cutoff to the median distance, with the exception of "citations received" which becomes insignificant but positive after excluding these matches. The lower threshold reduces the set of founders, as they lack controls. The main specification of below mean distance appears to be a good choice for the tradeoff between precision and bias.

\section{Falsification tests}

What are the chances that our matching process and estimation resulted purely from chance? We address this concern in two ways. In the first, we consider the full set of 2,337 founders and coinventors with the required patenting around the founding event. A non-founder co-inventor and founder are randomly switched. We then rerun the matching algorithm with these false founders and co-inventors. In unreported tables, the main results from the difference-in-difference estimator disappear. In the second robustness check, we perform the matching algorithm on the true founder 
and co-inventor inventors and instead randomly reassign the founder to one of the matched coinventors. The results in Table 10 make clear that the results nearly all disappear. ${ }^{31}$ The collection of evidence suggests that the results are not driven by chance or a misspecification in the matching process.

\section{Conclusion}

Using the employment and patenting histories of entrepreneurial founders, we document the patent characteristics that distinguish the inventor working at established and founding an entrepreneurial firm. A difference-in-difference estimator that uses a matched set of past co-workers and coinventors show economically large differences in innovation for the entrepreneurial founder. The founder produces $30 \%$ more patents which receive relatively more citations than her past co-workers and are more likely to be commercialized. Higher quality patents in VC-backed startups is not entirely surprising, so we provide richer detail about their characteristics. The patents produced also differ in their originality and generality, both of which are larger for founders. Overall, the set of patents produced by the entrepreneurial founder are of higher quality, more impactful and more likely to cite pre-founding work at the established firm. This collection of evidence is, to our knowledge, the first detailed look at how patent output differs at these two types of firms for the same inventor.

Our empirical strategy avoids issues such an unobserved heterogeneity of entrepreneurial founders, observable trends and some unobservable shocks. We attempt to rule out some unobserved timevarying trends with a cross-sectional comparison of startups formed in hot and cold markets. We find no statistical difference in these sub-samples, which is suggestive of a treatment effect of the startup firm on innovative output. Such effects could stem from firm size, organizational form or ownership form. This is an excellent area for future research.

The estimates show that patenting rates change almost immediately after founding, while the founder builds directly on prior work at the established firm. Insofar as the founders in our sample are exiting due to a rejected idea, we believe the differences in focus, originality and generality reveal

\footnotetext{
${ }^{31}$ One would expect one out of 20 to have a p-value of $5 \%$, so some may be significant.
} 
some of the frictions that impede innovation at the established firm. Other recent research provides similar conclusions in a different setting. Bernstein (2012) finds that the transition from private entrepreneurial firm to public firm reduces the quantity of fundamental, high quality research. Understanding why one firm type has an advantage or disadvantage will guide policies on supporting entrepreneurship or improving corporate innovation. 


\section{References}

Abadie, A., and G.W. Imbens. 2006. "Large sample properties of matching estimators for average treatment effects." Econometrica, 74(1): 235-267.

Agarwal, R., R. Echambadi, A.M. Franco, and MB Sarkar. 2004. "Knowledge Transfer Through Inheritance: Spin-Out Generation, Development and Survival." Academy of Management Journal, 47(4): 501-522.

Ai, C., and E.C. Norton. 2003. "Interaction terms in logit and probit models." Economics letters, 80(1): 123-129.

Azoulay, Pierre, J. Graff Zivin, and Jialan Wang. 2010. "Superstar Extinction." The Quarterly Journal of Economics, 125(2): 549-589.

Bernstein, Shai. 2012. "Does Going Public Affect Innovation?"

Bertrand, M., E. Duflo, and S. Mullainathan. 2000. "How Much Should We Trust Differencesin-Differences Estimates?" The Quarterly Journal of Economics, 119(1): 249-275.

Cassiman, Bruno, and Masako Ueda. 2006. "Optimal Project Rejection and New Firm Startups." Management Science, 52(2): 262-275.

Chatterji, Aaron K. 2008. "Spawned with a silver spoon? Entrepreneurial performance and innovation in the medical device industry." Strategic Management Journal, 30(2): 185-206.

Chemmanur, T.J., K. Krishnan, and D.K. Nandy. 2011. "How does venture capital financing improve efficiency in private firms? A look beneath the surface." Review of financial studies, 24(12): 4037-4090.

Da Rin, M., T.F. Hellmann, and M. Puri. 2011. "A survey of venture capital research." National Bureau of Economic Research.

Eriksson, T., and J. Moritz Kuhn. 2006. "Firm spin-offs in Denmark 1981-2000-patterns of entry and exit." International Journal of Industrial Organization, 24(5): 1021-1040. 
Gans, J.S., D.H. Hsu, and S. Stern. 2002. "When does start-up innovation spur the gale of creative destruction?" The RAND Journal of Economics, 33(4): 571-586.

Gompers, Paul, Josh Lerner, and David Scharfstein. 2005. "Entrepreneurial Spawning: Public Corporations and the Genesis of New Ventures, 1986 to 1999." Journal of Finance, 60(2): $577-614$.

Gonzalez-Uribe, Juanita. 2012. "Venture Capital and the Diffusion of Knowledge." Working Paper.

Hall, Bronwyn H., Adam B. Jaffe, and Manuel Trajtenberg. 2001. "The NBER Patent Citation Data File: Lessons, Insights and Methodological Tools."

Heckman, James, Hidehiko Ichimura, Jeffrey Smith, and Petra Todd. 1998. "Characterizing Selection Bias Using Experimental Data." Econometrica, 66(5): 1017-1098.

Heckman, James J, Hidehiko Ichimura, and Petra E Todd. 1997. "Matching as an Econometric Evaluation Estimator: Evidence from Evaluating a Job Training Programme." Review of Economic Studies, 64(4): 605-54.

Hellmann, Thomas. 2007. "When do employees become entrepreneurs?" Management science, 53(6): 919-933.

Hellman, T., and M. Puri. 2000. "The interaction between product market and financing strategy: The role of venture capital." Review of Financial Studies, 13(4): 959-984.

Hsu, D.H., and R.H. Ziedonis. 2007. "Patents as quality signals for entrepreneurial ventures." Unpublished working paper, University of Michigan.

Imbens, Guido W. 2004. "Nonparametric Estimation of Average Treatment Effects Under Exogeneity: A Review." The Review of Economics and Statistics, 86(1): 4-29.

Klepper, S. 2009. "Spinoffs: A review and synthesis." European Management Review, 6(3): 159171. 
Klepper, Steven, and Peter Thompson. 2010. "Disagreements and intra-industry spinoffs." International Journal of Industrial Organization, 28(5): 526-538.

Klepper, Steven, and Sally Sleeper. 2005. "Entry by Spinoffs." Management Science, 51(8): 1291-1306.

Kortum, Samuel, and Josh Lerner. 2000. "Assessing the Contribution of Venture Capital to Innovation." RAND Journal of Economics, 31(4): 674-692.

Lai, Ronald, Alexander D'Amour, Amy Yu, Ye Sun, and Lee Fleming. 2011. "Disambiguation and Co-authorship Networks of the U.S. Patent Inventor Database (1975 - 2010)."

Lerner, J., M. Sorensen, and P. Strömberg. 2011. "Private Equity and Long-Run Investment: The Case of Innovation." The Journal of Finance, 66(2): 445-477.

Malsberger, Brian. 2008. Covenants Not to Compete : A State-by-State Survey. BNA Books.

Marx, M., D. Strumsky, and L. Fleming. 2009. "Mobility, skills, and the Michigan noncompete experiment." Management Science, 55(6): 875-889.

Nanda, R., and M. Rhodes-Kropf. forthcoming. "Financing risk and innovation." Journal of Financial Economics.

Papke, Leslie E., and Jeffrey M. Wooldridge. 2008. "Panel data methods for fractional response variables with an application to test pass rates." Journal of Econometrics, 145(1-2): 121133.

Puri, M., and R. Zarutskie. forthcoming. "On the lifecycle dynamics of venture-capital-and non-venture-capital-financed firms."

Singh, Jasjit, and Ajay Agrawal. 2011. "Recruiting for Ideas: How Firms Exploit the Prior Inventions of New Hires." Management Science, 57(1): 129-150. 


\section{$9 \quad$ Tables and Figures}

Figure 1: Original Patent Sub-class Categories Use Over Time

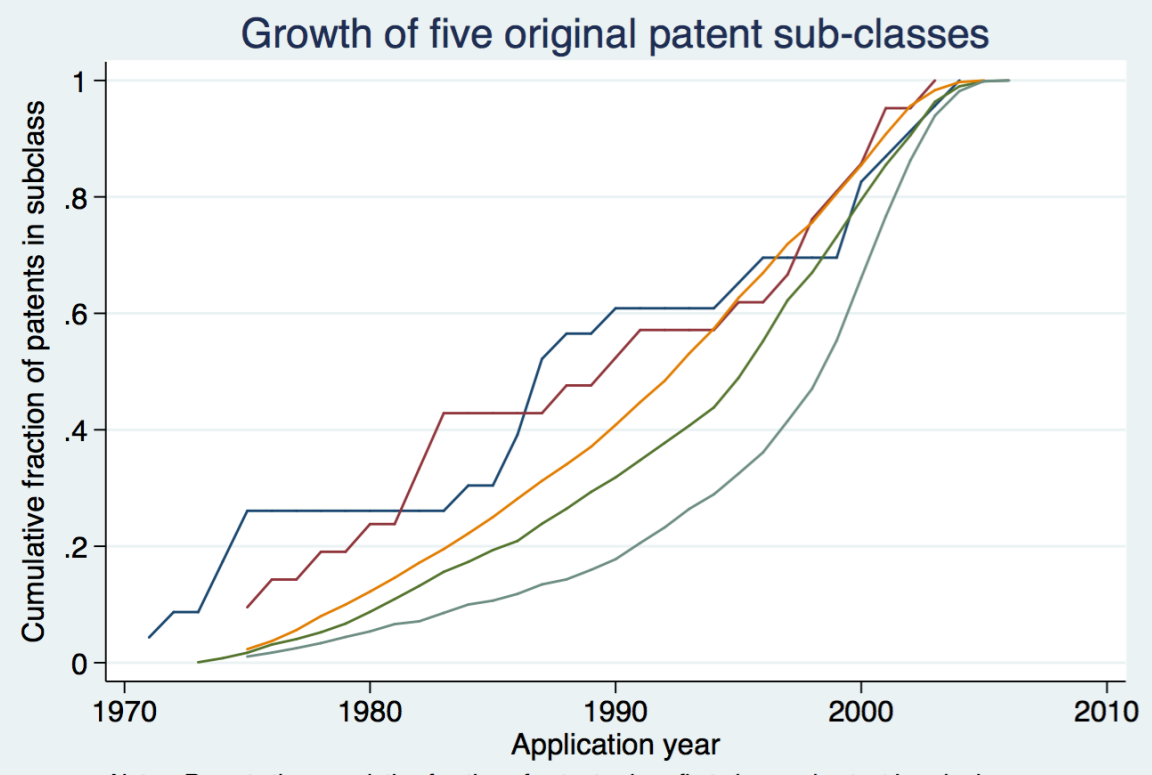

Notes: Reports the cumulative fraction of patents since first observed patent in sub-class.

The figure reports the cumulative fractions applied for in five random original patent sub-classes. That is, for each year after the first patent is classified in the sub-class, we calculate the fraction of the full history of that sub-class were applied for in each year. All sub-classes will have a 1 for the final year of this sample (2007) and 0 in the first observed year. 
Figure 2: Patent applications around startup

The figure reports the average number of patents applied for in each year around the startup event for the entrepreneurial founders in the sample. Year 0 is the startup year. The bars represent the average patent rates across founders. The dashed line presents the empirical cumulative distribution function for the average fraction of patents applied for between $t=0$ and $t=5$. For example, the average startup applied for $25 \%$ of their total patents in the first founding year.

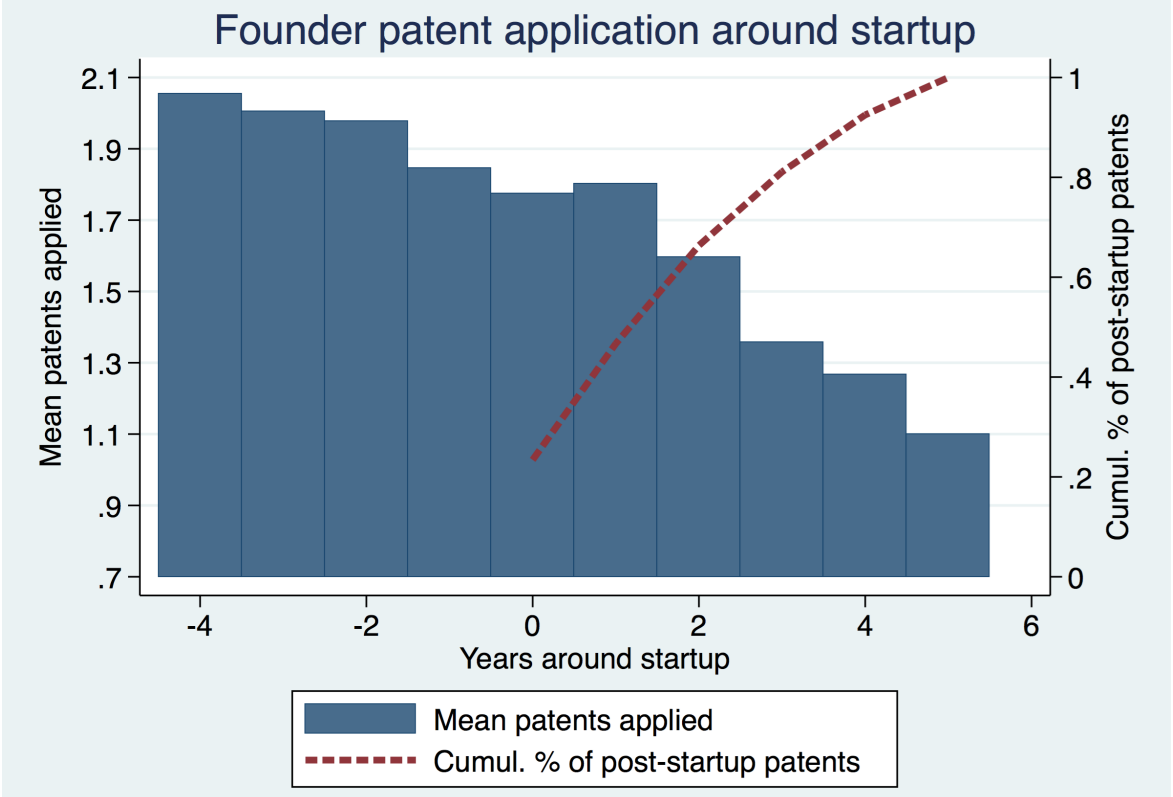


Figure 3: Patents over time: founders vs. co-inventors

Notes: Estimated coefficients $\rho_{t}$ from the difference-in-difference and fixed effects estimator 1 for the outcome variable patents per year. The excluded event time is $t=-1$, which is set to zero in the figure. Estimation is done with poisson fixed effects where the standard errors are clustered at the group fixed effect.

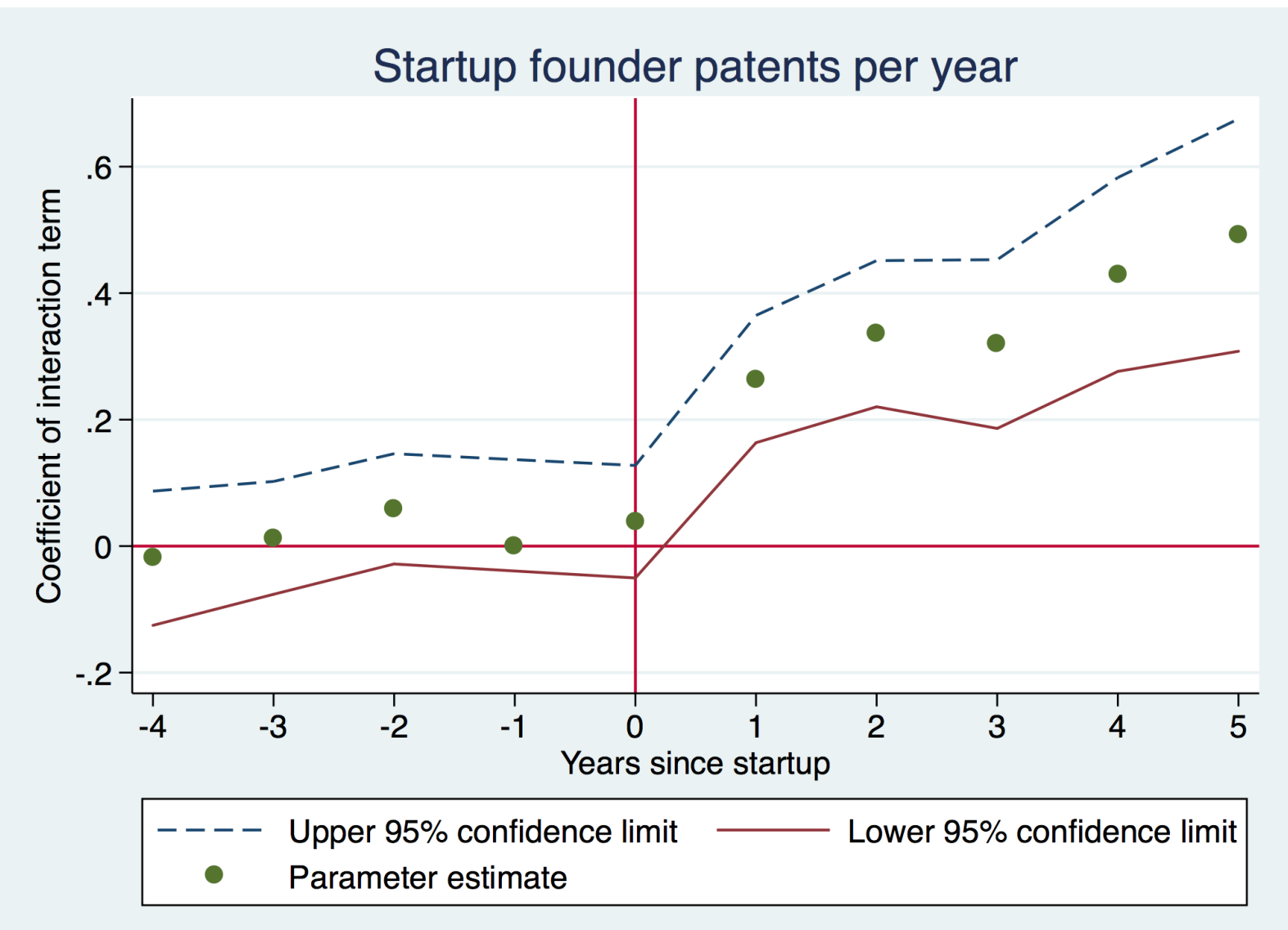


Figure 4: Pre-startup patent self-citations received: founders vs. co-inventors

Notes: Estimated coefficients $\rho_{t}$ from the difference-in-difference and fixed effects estimator 1 for the outcome variable that counts number of self-citations received by the stock of pre-startup patents as of $t$ inventor $i$ at period $k$ for all patents applied for at or prior to $k(k \geq-4)$. The excluded event time is $t=-1$, which is set to zero in the figure. Estimation is done with poisson fixed effects where the standard errors are clustered at the group fixed effect.

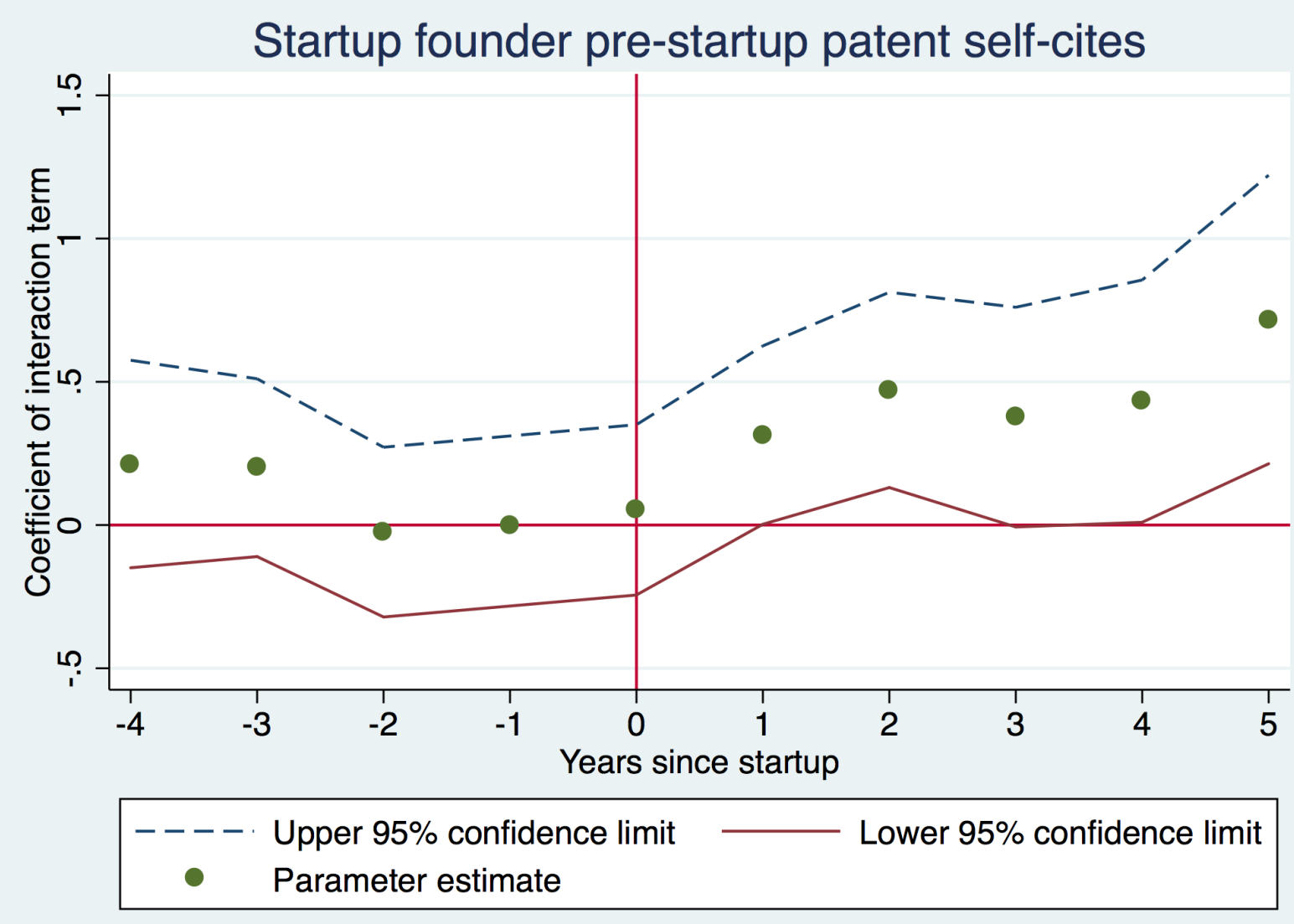


Figure 5: Hot and cold markets: Medical Devices and Semiconductors

Notes: Figures present the total number of new entrepreneurial firms financed by venture capital in two industries: medical devices and semiconductors. The solid line shows the count, while the red and blue shaded region depict years that are "hot" and "cold" respectively. A "hot" market is one whose growth in the number of new firms is in the top quartile of growth over the sample period (bottom quartile for "cold" markets).

\section{Hot and cold markets by new VC-backed firms}
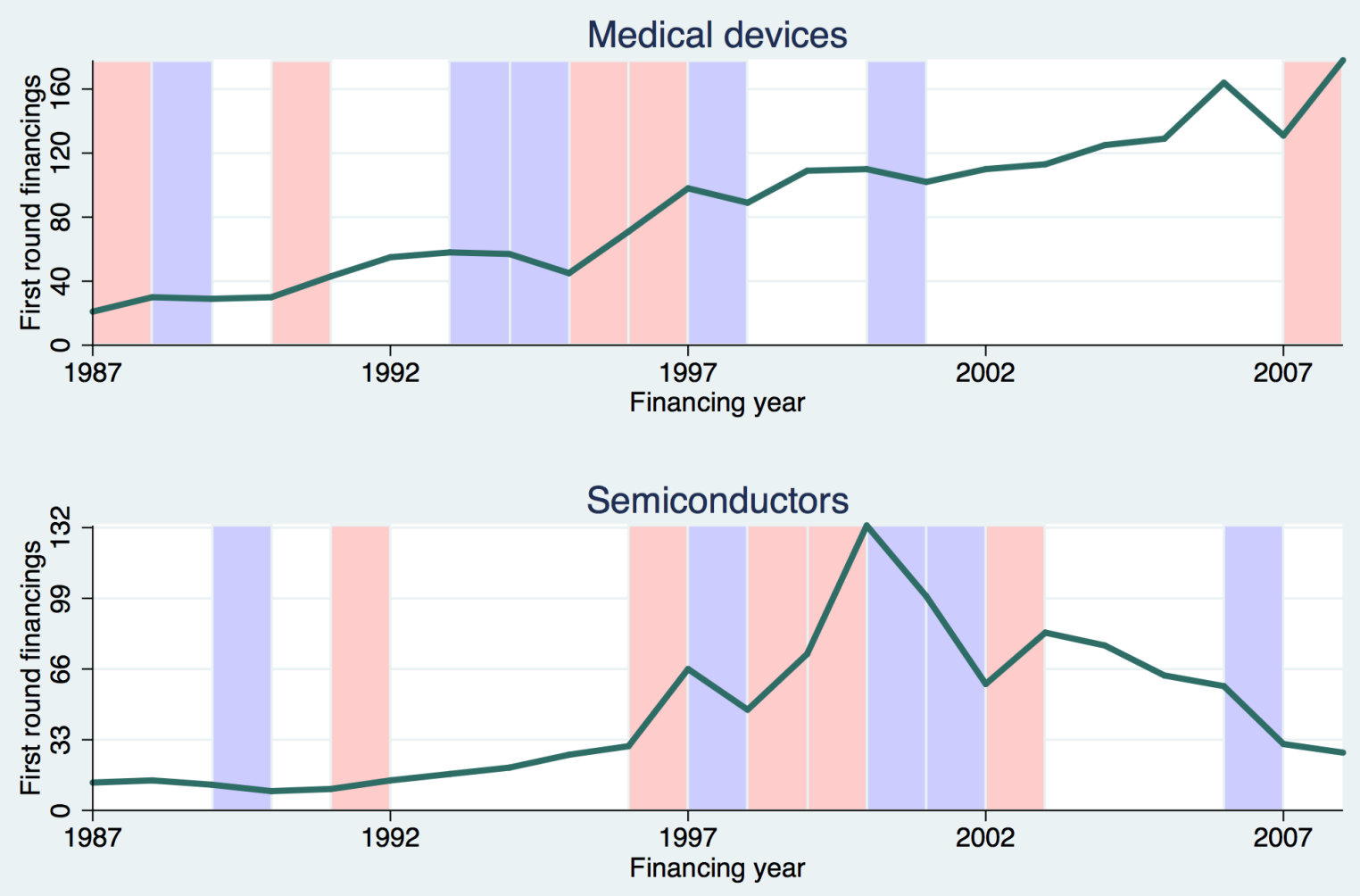
Table 1: Most common previous employers for all entrepreneurial firm founders

Notes: Table presents a tabulation of the last known employer for the set of all VC-backed entrepreneurial founders sorted by frequency.

\begin{tabular}{|ll|}
\hline \multicolumn{2}{|c|}{ Employer Name } \\
\hline IBM & Pfizer \\
Oracle & KPMG \\
Microsoft & Accenture \\
Sun Microsystems & Novell \\
Hewlett-Packard & Compaq \\
Intel & Deloitte \& Touche \\
Cisco Systems & Symantec \\
Lucent Technologies & Genentech \\
Motorola & Yahoo! \\
Nortel Networks & Stanford University \\
Ernst \& Young & AOL \\
AT\&T & National Semiconductor \\
PricewaterhouseCoopers & EMC \\
3Com & Digital Equipment \\
Andersen Consulting & Xerox \\
PeopleSoft & Siebel Systems \\
Arthur Andersen & Synopsys \\
Texas Instruments & i2 Technologies \\
Silicon Graphics & Computer Associates \\
Cadence Design Systems & General Electric \\
Sybase & Nortel \\
McKinsey \& Company & EDS \\
Lucent & Medtronic \\
Apple Computer & LSI Logic \\
Johnson \& Johnson & Alcatel \\
Cisco & Cambridge Technology Partners \\
Hewlett Packard & Boston Scientific \\
Intuit & Tivoli Systems \\
\hline & \\
\hline
\end{tabular}


Table 2: Variable description

Notes: Description of the main patent dependent variables used throughout the paper.

\begin{tabular}{|c|c|}
\hline Variable & Description \\
\hline \# Patents & $\begin{array}{l}\text { The average number of patents applied for each year in the windows } \\
{[-4,0) \text { and }[0,5] \text {. }}\end{array}$ \\
\hline Originality & $\begin{array}{l}\text { The originality (adjusted) measure using the sub-class of patents cited } \\
\text { in an inventor's patents in each window. Patents that cite a larger } \\
\text { set of sub-classes are more original. The adjustment (see Hall, Jaffe and } \\
\text { Trajtenberg (2001)) addresses the inherent bias in the standard measure. }\end{array}$ \\
\hline Citations received & $\begin{array}{l}\text { For the pre-startup patents, the total number of citations received at } \\
t=-1 \text { for all patents applied for in }[-4,0) \text {. For the post-startup patents, } \\
\text { the total number of citations received at } t=5 \text { for all patents applied for } \\
\text { in }[0,5] \text {. }\end{array}$ \\
\hline $\begin{array}{l}\text { Citations received } \\
\text { (non-self) }\end{array}$ & $\begin{array}{l}\text { Same measure as "Citations received" except self-citations received by } \\
\text { the same inventor are excluded. A self-citation is defined at the inventor- } \\
\text { patent level. }\end{array}$ \\
\hline Generality & $\begin{array}{l}\text { The generality (adjusted) measure using the sub-class of patents citing } \\
\text { the patent in each window. As in "Citations received," this variable is } \\
\text { measured for the two sets of patent stocks at } t=-1 \text { and } t=4 \text {. Patents } \\
\text { with higher generality are cited by a larger set of patent sub-classes. } \\
\text { The adjustment (see Hall, Jaffe and Trajtenberg (2001)) addresses the } \\
\text { inherent bias in the measure related to citations counts. }\end{array}$ \\
\hline$\%$ Winners & $\begin{array}{l}\text { For each patent sub-class and year, we calculate the number of citations } \\
\text { received } 5 \text { years after patent grant. A patent is a "winner" if it is in the } \\
\text { top } 10 \% \text { this citation count within the same application year and patent } \\
\text { classification. }\end{array}$ \\
\hline $\begin{array}{l}\% \text { self citations } \\
\text { made }\end{array}$ & $\begin{array}{l}\text { A number in }[0,1] \text { that measures the fraction of a patents citations made } \\
\text { that are self-citations. A self-citation is defined at the inventor-level, so } \\
\text { a patent with multiple inventors can have different values of "\% self- } \\
\text { citations made." }\end{array}$ \\
\hline CIP & $\begin{array}{l}\text { A continuation-in-part (CIP) creates a relationship of a "parent" and } \\
\text { "child" patent. A patent is a (CIP) if it references itself as a } \\
\text { continuation-in-part of an already applied for patent. A CIP typically } \\
\text { adds new claims to the parent patent while the latter is still pending } \\
\text { grant. CIPs are often used to add commercial application/uses to an } \\
\text { existing technology. }\end{array}$ \\
\hline OCL Age & $\begin{array}{l}\text { The NBER patent data includes the original patent class/sub-class } \\
\text { (OCL) category recorded at the time of patent application. For the } \\
\text { full history of each OCL, we calculate the cumulative fraction of the } \\
\text { within-sub-class patents have been applied for as of year } t \text {. If } 20 \% \text { of all } \\
\text { patents in the OCL sub-class were applied for in its first year, then they } \\
\text { would have a value of } 0.2 \text {. Patents filed in the final year of the sample } \\
\text { (2006) each have a value of } 1 \text {. See Figure } 1 \text { for example time series of } \\
\text { this measure. }\end{array}$ \\
\hline $\begin{array}{l}\text { Pre-startup self- } \\
\text { citations }\end{array}$ & $\begin{array}{l}\text { The number of self-citations received by the stock of pre-startup patents } \\
\text { at two periods in time: } t=-1 \text { and } t=5 \text {. }\end{array}$ \\
\hline $\begin{array}{l}\text { Importance for- } \\
\text { ward }\end{array}$ & $\begin{array}{l}\text { A characterization of the number of citations received and the number } \\
\text { of citations received by the patents that cite a patent. The paper uses } \\
\text { a weight of } .5 \text { for the second-degree citations. }\end{array}$ \\
\hline
\end{tabular}


Table 3: Sources of entrepreneurial founders with patents

Notes: Tabulation of the assignees associated with the entrepreneurial firm founders who have a matched coinventor and at least one patent before and after the startup event. Although we exclude patents at universities and government, this list includes all past employers of the startup founders with at least five founders.

\begin{tabular}{|c|c|}
\hline & Count \\
\hline IBM & 82 \\
\hline $\mathrm{AT} \& \mathrm{~T}$ & 59 \\
\hline Lucent Technologies Inc & 52 \\
\hline Intel Corporation & 43 \\
\hline Sun Microsystems Inc & 36 \\
\hline Microsoft Corporation & 26 \\
\hline Cisco Technology Inc & 25 \\
\hline Motorola Inc & 25 \\
\hline Hewlett-Packard Company & 23 \\
\hline Advanced Micro Devices Inc & 18 \\
\hline Apple Inc & 18 \\
\hline Digital Equipment Corporation & 18 \\
\hline National Semiconductor Corporation & 18 \\
\hline University of California & 18 \\
\hline Applied Materials Inc & 14 \\
\hline 3Com Corporation & 13 \\
\hline General Electric Company & 13 \\
\hline Massachusetts Institute Of Technology & 12 \\
\hline Stanford University & 12 \\
\hline Compaq Computer Corporation & 10 \\
\hline Scimed Life Systems Inc & 10 \\
\hline Silicon Graphics Inc & 10 \\
\hline Texas Instruments Incorporated & 10 \\
\hline Xerox Corporation & 10 \\
\hline Boston Scientific Scimed Inc & 9 \\
\hline Genentech Inc & 9 \\
\hline Advanced Cardiovascular Systems Inc & 8 \\
\hline Agilent Technologies Inc & 8 \\
\hline Baxter International Inc & 8 \\
\hline Becton Dickinson And Company & 8 \\
\hline Bristolmyers Squibb Company & 8 \\
\hline Broadcom Corporation & 8 \\
\hline Medtronic Inc & 8 \\
\hline Micron Technology Inc & 8 \\
\hline Agere Systems Guardian Corp & 7 \\
\hline Cirrus Logic Inc & 7 \\
\hline Cornell Research Foundation Inc & 7 \\
\hline Medtronic Vascular Inc & 7 \\
\hline Rambus Inc & 7 \\
\hline The Scripps Research Institute & 7 \\
\hline Unisys Corporation & 7 \\
\hline Agere Systems Inc & 6 \\
\hline C R Bard Inc & 6 \\
\hline California Institute Of Technology & 6 \\
\hline Ciena Corporation & 6 \\
\hline Emc Corporation & 6 \\
\hline Merck Co Inc & 6 \\
\hline Nortel Networks Limited & 6 \\
\hline Qualcomm Incorporated & 6 \\
\hline Sandisk Corporation & 6 \\
\hline Observations & 760 \\
\hline
\end{tabular}


Table 4: Entrepreneurial firms: Pre- and post-match

Notes: Table reports several entrepreneurial firm characteristics of the final sample of firms after the matching process (see Section 3) and those excluded from the final sample. Founders and their firms are dropped if there is no quality match on observables or their quality pre-founding match stops patenting after founding. Some entrepreneurial firms have co-founders (82 in the final sample and 107 in the dropped sample). "Founding year" is the entrepreneurial firm's founding year, "Information Tech." is the fraction of the sample in IT and "Healthcare" is the fraction of firms in healthcare. "\% publicly-held," "\% Acquired" and "\% still private" report the fraction of firms by exit status (as of quarter two of 2012). "California" and "Massachusetts" report the fraction of founding states. "First capital raised $(\mathrm{m})$ " is the capital raised by the firms in their first VC financing (in millions). The third column reports the differences in means and two-side t-test results. Significance: * $p<0.10,{ }^{* *} p<0.05,{ }^{* * *} p<0.01$.

\begin{tabular}{|c|c|c|c|}
\hline & Post-match & No matches & Diff./s.e. \\
\hline Founding year & 1999.7 & 2000.2 & $\begin{array}{c}-0.574^{* *} \\
(0.211)\end{array}$ \\
\hline Information Tech. & 0.590 & 0.587 & $\begin{array}{l}0.00277 \\
(0.0205)\end{array}$ \\
\hline Healthcare & 0.324 & 0.259 & $\begin{array}{c}0.0645^{* * *} \\
(0.0187)\end{array}$ \\
\hline$\%$ publicly-held & 0.109 & 0.0946 & $\begin{array}{c}0.0149 \\
(0.0125)\end{array}$ \\
\hline$\%$ Acquired & 0.370 & 0.322 & $\begin{array}{c}0.0475^{*} \\
(0.0197)\end{array}$ \\
\hline$\%$ still private & 0.288 & 0.361 & $\begin{array}{c}-0.0727^{* * *} \\
(0.0197)\end{array}$ \\
\hline California & 0.540 & 0.489 & $\begin{array}{c}0.0511^{*} \\
(0.0208)\end{array}$ \\
\hline Massachusetts & 0.106 & 0.127 & $\begin{array}{l}-0.0211 \\
(0.0136)\end{array}$ \\
\hline First capital raised $(\mathrm{m})$ & 6.298 & 6.023 & $\begin{array}{c}0.275 \\
(0.361)\end{array}$ \\
\hline Firms & 846 & 624 & \\
\hline
\end{tabular}


Table 5: Summary statistics: founders and best matches co-inventors

Notes: Summary statistics of the main dependent variables of interest for the sample of founders and the coinventor controls that have a below median Mahalanobis distance (see Section X). Table 2 defines the variables. "Growth in X $(T-1, T)$ " computes growth in periods before and after the startup where $T$ is the end of each time interval $(t=-1$ and $t=5)$. The "All" column includes one observation for pre- and post-startup patent stocks for co-inventors and founders. "Before" and "After" consider only the patents for each founder's preand post-startup patent stock (i.e. $t \in[-4,-1]$ and $t \in[0,5]$ ). Means reported with standard deviations in parentheses.

\begin{tabular}{|c|c|c|c|c|c|}
\hline Variable & Total & Control Before & Founder Before & Control After & Founder After \\
\hline Patents per year & $\begin{array}{c}1.34 \\
(1.656)\end{array}$ & $\begin{array}{c}1.67 \\
(1.488)\end{array}$ & $\begin{array}{c}1.81 \\
(1.738)\end{array}$ & $\begin{array}{c}.783 \\
(1.369)\end{array}$ & $\begin{array}{c}1.46 \\
(2.213)\end{array}$ \\
\hline Growth in patent stock & $\begin{array}{l}1.06 \\
(.168)\end{array}$ & $\begin{array}{c}1.1 \\
(.155)\end{array}$ & $\begin{array}{l}1.11 \\
(.206)\end{array}$ & $\begin{array}{c}1.02 \\
(.065)\end{array}$ & $\begin{array}{c}1.07 \\
(.2831)\end{array}$ \\
\hline Growth in patent stock $(T-2, T)$ & $\begin{array}{l}1.19 \\
(.4115)\end{array}$ & $\begin{array}{l}1.282 \\
(.387)\end{array}$ & $\begin{array}{l}1.43 \\
(.709)\end{array}$ & $\begin{array}{l}1.056 \\
(.147)\end{array}$ & $\begin{array}{l}1.156 \\
(.428)\end{array}$ \\
\hline Growth in cites received $(T-1, T)$ & $\begin{array}{c}1.23 \\
(.501)\end{array}$ & $\begin{array}{l}1.36 \\
(.359)\end{array}$ & $\begin{array}{l}1.37 \\
(.457)\end{array}$ & $\begin{array}{l}1.09 \\
(.642)\end{array}$ & $\begin{array}{l}1.15 \\
(.279)\end{array}$ \\
\hline Growth in cites received $(T-2, T)$ & $\begin{array}{c}1.76 \\
(1.703)\end{array}$ & $\begin{array}{c}2.21 \\
(1.707)\end{array}$ & $\begin{array}{c}2.47 \\
(2.799)\end{array}$ & $\begin{array}{c}1.24 \\
(1.126)\end{array}$ & $\begin{array}{c}1.44 \\
(.999)\end{array}$ \\
\hline Growth in originality $(T-1, T)$ & $\begin{array}{l}1.006 \\
(.051)\end{array}$ & $\begin{array}{l}1.006 \\
(.053)\end{array}$ & $\begin{array}{l}1.006 \\
(.061)\end{array}$ & $\begin{array}{l}1.003 \\
(.037)\end{array}$ & $\begin{array}{c}1.01 \\
(.063)\end{array}$ \\
\hline Growth in originality $(T-2, T)$ & $\begin{array}{l}1.021 \\
(.136)\end{array}$ & $\begin{array}{l}1.026 \\
(.132)\end{array}$ & $\begin{array}{l}1.05 \\
(.264)\end{array}$ & $\begin{array}{c}1.01 \\
(.062)\end{array}$ & $\begin{array}{l}1.02 \\
(.11)\end{array}$ \\
\hline First year patent & $\begin{array}{c}1989.99 \\
(6.19)\end{array}$ & $\begin{array}{l}1989.9 \\
(5.99)\end{array}$ & $\begin{array}{c}1990.02 \\
(6.7)\end{array}$ & & \\
\hline Total non-self cites received & $\begin{array}{c}108.23 \\
(128.55)\end{array}$ & $\begin{array}{c}87.84 \\
(113.22)\end{array}$ & $\begin{array}{c}86.71 \\
(121.91)\end{array}$ & $\begin{array}{c}127.7 \\
(136.72)\end{array}$ & $\begin{array}{c}132.74 \\
(138.92)\end{array}$ \\
\hline Avg. Originality (adj.) & $\begin{array}{c}.508 \\
(.277)\end{array}$ & $\begin{array}{c}.566 \\
(.219)\end{array}$ & $\begin{array}{c}.554 \\
(.216)\end{array}$ & $\begin{array}{c}.401 \\
(.329)\end{array}$ & $\begin{array}{c}.596 \\
(.221)\end{array}$ \\
\hline Generality $(t=-1,4)$ & $\begin{array}{c}.769 \\
(.187)\end{array}$ & $\begin{array}{c}.75 \\
(.199)\end{array}$ & $\begin{array}{c}.72 \\
(.244)\end{array}$ & $\begin{array}{c}.8 \\
(.152)\end{array}$ & $\begin{array}{l}.788 \\
(.162)\end{array}$ \\
\hline Fraction patent is CIP & $\begin{array}{c}.1 \\
(.234)\end{array}$ & $\begin{array}{l}.05 \\
(.151)\end{array}$ & $\begin{array}{l}.038 \\
(.125)\end{array}$ & $\begin{array}{l}.139 \\
(.283)\end{array}$ & $\begin{array}{l}.191 \\
(.302)\end{array}$ \\
\hline Fraction self-cites made & $\begin{array}{l}.033 \\
(.081)\end{array}$ & $\begin{array}{l}.0385 \\
(.082)\end{array}$ & $\begin{array}{l}.0387 \\
(.087)\end{array}$ & $\begin{array}{c}.024 \\
(.067)\end{array}$ & $\begin{array}{l}.0366 \\
(.1)\end{array}$ \\
\hline Fraction winners & $\begin{array}{c}.139 \\
(.226)\end{array}$ & $\begin{array}{c}.167 \\
(.244)\end{array}$ & $\begin{array}{c}.174 \\
(.226)\end{array}$ & $\begin{array}{c}.099 \\
(.199)\end{array}$ & $\begin{array}{c}.118 \\
(.209)\end{array}$ \\
\hline Avg. age of patent class & $\begin{array}{c}.737 \\
(.178)\end{array}$ & $\begin{array}{l}.683 \\
(.168)\end{array}$ & $\begin{array}{l}.657 \\
(.169)\end{array}$ & $\begin{array}{c}.842 \\
(.142)\end{array}$ & $\begin{array}{l}.828 \\
(.152)\end{array}$ \\
\hline Number obs. & 7,632 & 2,929 & 2,897 & 903 & 903 \\
\hline
\end{tabular}


Table 6: Changes in patent classes around startup

Notes: Table characterizes the changes in patenting activity by industry class for startup founders and their co-inventor controls. The estimation specification is found in equation (4) using the conditional logit. Odds ratio (i.e. exponentiated coefficients) reported, where greater than 1 implies relatively higher probabilities. Each set of columns - (1)/(3) and (2)/(4) - present conditional logit estimates of two dummies variables. For each of the seven patent classes, an inventor can have a defined "Decrease" dummy if she (i) had positive patenting in that class pre-startup. The dummy is 1 if the fraction of patents in that class post-startup falls. The dummy is undefined if not pre-startup patenting occurs in that class. An inventor has multiple observations if she has multiple pre-startup patent classes with positive patenting. The "New?" dependent variable is defined for all inventors-classes where the inventor had zero patents in the pre-startup period. The dummy is 1 if there is an increase in patenting from 0 in the post-startup period. The group fixed effect is the founder-co-inventor controls. Columns 3 and 4 repeat the regressions on the sub-sample of firms that are have low covenant not to compete (CNC) states (i.e. below the median index measure in Malsberger (2008)) in the pre-period. The index comes from the survey of laws in Malsberger (2008). The control "Founder" is equal to 1 if the inventor was a founder and the coefficient reports the relative higher or lower probability the founder decreased her patenting in that patent class. "Change in patents" is the difference in total patents between the pre- and post-period (pre minus post). "Share at $t=-1$ " is the share of patents in the given patent class for this stock of patents. "Class N" are dummy variables for each of the seven patent classes (the excluded class is class 1 ). The patent class definitions are found in Section 5.1. "Cohort FE" are fixed effects for each founder-co-inventor group, where co-inventors are chosen according to the matching process described in Section 3. Standard errors clustered at the founder-co-inventor group shown in parentheses. Significance: ${ }^{*} p<0.10,{ }^{* *} p<0.05,{ }^{* * *} p<0.01$.

\begin{tabular}{|c|c|c|c|c|}
\hline & \multirow{2}{*}{$\begin{array}{c}\text { Decrease? } \\
(1) \\
\end{array}$} & \multirow{2}{*}{$\begin{array}{c}\text { New? } \\
(2) \\
\end{array}$} & \multirow{2}{*}{$\begin{array}{c}\text { Decrease? } \\
\text { Low CN } \\
(3)\end{array}$} & \multirow{2}{*}{$\begin{array}{c}\text { New? } \\
\text { States } \\
(4)\end{array}$} \\
\hline & & & & \\
\hline Founder & $\begin{array}{c}1.775^{\text {*** }} \\
(0.128)\end{array}$ & $\begin{array}{c}1.130 \\
(0.112)\end{array}$ & $\begin{array}{c}1.780^{* * *} \\
(0.169)\end{array}$ & $\begin{array}{c}1.019 \\
(0.148)\end{array}$ \\
\hline Share $t-1$ & $\begin{array}{l}0.677^{* * *} \\
(0.0870)\end{array}$ & & $\begin{array}{c}0.878 \\
(0.153)\end{array}$ & \\
\hline Change in patents & $\begin{array}{c}0.967^{* * *} \\
(0.00648)\end{array}$ & $\begin{array}{c}0.974^{* * *} \\
(0.00634)\end{array}$ & $\begin{array}{c}0.968^{* * *} \\
(0.00624)\end{array}$ & $\begin{array}{c}0.969^{* * *} \\
(0.00755)\end{array}$ \\
\hline Class 2 & $\begin{array}{c}1.723^{* * *} \\
(0.322)\end{array}$ & $\begin{array}{c}3.058^{* * *} \\
(0.609)\end{array}$ & $\begin{array}{l}1.756^{* *} \\
(0.431)\end{array}$ & $\begin{array}{c}2.857^{* * *} \\
(0.772)\end{array}$ \\
\hline Class 3 & $\begin{array}{c}1.087 \\
(0.244)\end{array}$ & $\begin{array}{c}4.260^{* * *} \\
(0.956)\end{array}$ & $\begin{array}{c}0.998 \\
(0.301)\end{array}$ & $\begin{array}{c}4.945^{* * *} \\
(1.551)\end{array}$ \\
\hline Class 4 & $\begin{array}{c}0.851 \\
(0.182)\end{array}$ & $\begin{array}{c}5.965^{* * *} \\
(1.358)\end{array}$ & $\begin{array}{c}0.783 \\
(0.220)\end{array}$ & $\begin{array}{c}6.213^{* * *} \\
(1.960)\end{array}$ \\
\hline Class 5 & $\begin{array}{c}0.946 \\
(0.189)\end{array}$ & $\begin{array}{c}9.450^{* * *} \\
(2.068)\end{array}$ & $\begin{array}{c}0.986 \\
(0.261)\end{array}$ & $\begin{array}{c}8.998^{* * *} \\
(2.697)\end{array}$ \\
\hline Class 6 & $\begin{array}{c}2.453^{* * *} \\
(0.722)\end{array}$ & $\begin{array}{c}1.360 \\
(0.307)\end{array}$ & $\begin{array}{c}2.040 \\
(0.934)\end{array}$ & $\begin{array}{c}1.149 \\
(0.342)\end{array}$ \\
\hline Class 7 & $\begin{array}{c}1.259 \\
(0.257) \\
\end{array}$ & $\begin{array}{c}2.649^{* * *} \\
(0.523) \\
\end{array}$ & $\begin{array}{c}1.202 \\
(0.320) \\
\end{array}$ & $\begin{array}{c}2.750^{* * *} \\
(0.729) \\
\end{array}$ \\
\hline Observations & 4784 & 6235 & 2600 & 3364 \\
\hline Pseudo- $R^{2}$ & 0.0520 & 0.0996 & 0.0465 & 0.108 \\
\hline Total founders & 636 & 425 & 338 & 229 \\
\hline Cohort FE? & $\mathrm{Y}$ & $\mathrm{Y}$ & $\mathrm{Y}$ & $\mathrm{Y}$ \\
\hline
\end{tabular}


Table 7: Comparing current and backward-looking patent characteristics: Within-founder

Notes: Estimates from regressions with a startup founder before and after the startup event. A founder is included in the sample if she has at least one patent before and after the founding. Dependent variables in Panel A focus on current or backward-looking characteristics of patents. See Table 2 for definitions. Panel B dependent variables consider forward-looking measures. For all dependent variables, the weighted means are computed in the intervals $[-4,-1]$ and $[0,5]$ using the number of patents applied in each event year. "Poisson FE" uses the fixed effects poisson regression. "FE" is the standard fixed effect regression. "GLM FE" uses the Papke and Wooldridge (2008) panel method for fractional response dependent variables. "Cohort FE?" is the fixed effect for each founder-co-inventor group using the matching process described in Section 3. Variable counts and founder samples differ across columns for several reasons. Some patent lack sufficient citations to compute originality and patent class age is only available for patents applied prior to 2007. "Pre-startup self-cites rec." cohorts are excluded if there is no variation in the dependent variable (typically 0). Both the "Winners" and "Imp. Forward" require many years post-founding observations to compute, so the sample includes more recently founded firms. Robust standard errors in parentheses. Significance: ${ }^{*} p<0.10,{ }^{* *} p<0.05,{ }^{* * *} p<0.01$.

\begin{tabular}{|c|c|c|c|c|c|}
\hline & \multicolumn{5}{|c|}{ Panel A: Current or backward-looking measures } \\
\hline & \# Patents & Originality & $\begin{array}{c}\% \text { self cites } \\
\text { made }\end{array}$ & Continue-in-part & $\begin{array}{l}\text { Patent } \\
\text { class age }\end{array}$ \\
\hline Post-startup & $\begin{array}{l}-0.0373 \\
(0.0485)\end{array}$ & $\begin{array}{l}0.0434^{* * *} \\
(0.00727)\end{array}$ & $\begin{array}{c}0.0359 \\
(0.0392)\end{array}$ & $\begin{array}{c}0.136^{* * *} \\
(0.00770)\end{array}$ & $\begin{array}{l}0.640^{* * *} \\
(0.0118)\end{array}$ \\
\hline Constant & & $\begin{array}{c}0.551^{* * *} \\
(0.00363)\end{array}$ & $\begin{array}{r}-1.833^{* * *} \\
(0.0319)\end{array}$ & $\begin{array}{l}0.0356^{* * *} \\
(0.00384)\end{array}$ & $\begin{array}{l}0.384^{* * *} \\
(0.0136)\end{array}$ \\
\hline $\begin{array}{l}\text { Observations } \\
R^{2} \text {-within } \\
\text { Psuedo- } R^{2} \\
\text { Estimator } \\
\text { FE? } \\
\text { Startup year FE? }\end{array}$ & $\begin{array}{c}\text { Poisson FE } \\
\mathrm{Y} \\
\mathrm{Y}\end{array}$ & $\begin{array}{c}2238 \\
0.0311\end{array}$ & $\begin{array}{c}2252 \\
0.000259 \\
\text { GLM FE } \\
\text { Y } \\
\text { Y }\end{array}$ & $\begin{array}{c}\text { GLM FE } \\
\text { Y } \\
Y\end{array}$ & $\begin{array}{c}0.219 \\
\mathrm{FE} \\
\mathrm{Y} \\
\mathrm{Y}\end{array}$ \\
\hline Startup year FE? & $\begin{array}{c}\text { Pre-startup } \\
\text { self-cites rec. }\end{array}$ & $\begin{array}{r}\text { Pane } \\
\text { Generality }\end{array}$ & $\begin{array}{c}\text { B: Forward-loo } \\
\text { Non-self Cites } \\
\text { Received } \\
\end{array}$ & $\begin{array}{l}\text { ing measures } \\
\% \text { Winners }\end{array}$ & Imp. Forward \\
\hline Post-startup & $\begin{array}{l}0.0566 \\
(0.106)\end{array}$ & $\begin{array}{l}0.0876^{* * *} \\
(0.00691)\end{array}$ & $\begin{array}{l}0.595^{* * *} \\
(0.0400)\end{array}$ & $\begin{array}{c}-0.222^{* * *} \\
(0.0414)\end{array}$ & $\begin{array}{c}-0.389^{* * *} \\
(0.0194)\end{array}$ \\
\hline Constant & & $\begin{array}{c}0.698^{* * *} \\
(0.00357)\end{array}$ & & $\begin{array}{c}-0.941^{* * *} \\
(0.0325)\end{array}$ & $\begin{array}{c}4.898^{* * *} \\
(0.00780)\end{array}$ \\
\hline Observations & 786 & 2164 & 2236 & 1794 & 1076 \\
\hline$R^{2}$-within & 0000262 & 0.133 & 00546 & 00113 & 0.597 \\
\hline Estimator & Poisson FE & $\mathrm{FE}$ & Poisson FE & GLM FE & $\mathrm{FE}$ \\
\hline FE? & Y & Y & Y & $\mathrm{Y}$ & $\mathrm{Y}$ \\
\hline Startup year FE? & Y & $\mathrm{Y}$ & $\mathrm{Y}$ & Y & Y \\
\hline
\end{tabular}


Table 8: Backward and forward-looking patent characteristics: difference-in-difference

Notes: Estimates from a difference-in-difference regression with a startup founder and co-inventor controls. The co-inventor controls are included if they are below the median Mahalanobis distance across all matches (see Section 3). A founder is included in the sample if she has at least one patent before and after the founding. Dependent variables in Panel A focus on current or backward-looking characteristics of patents. See Table 2 for definitions. Panel B dependent variables consider forward-looking measures. For all dependent variables, the weighted means are computed in the intervals $[-4,-1]$ and $[0,5]$ using the number of patents applied in each event year. "Poisson FE" uses the fixed effects poisson regression. "FE" is the standard fixed effect regression. "GLM FE" uses the Papke and Wooldridge (2008) panel method for fractional response dependent variables. "Cohort FE?" is the fixed effect for each founder-co-inventor group using the matching process described in Section 3. Variable counts and founder samples differ across columns for several reasons. Some patent lack sufficient citations to compute originality and patent class age is only available for patents applied prior to 2007. "Pre-startup self-cites rec." cohorts are excluded if there is no variation in the dependent variable (typically $0)$. Both the "Winners" and "Imp. Forward" require many years post-founding observations to compute, so the sample includes more recently founded firms. Standard errors clustered at the founder-co-inventor group reported in parentheses. Significance: ${ }^{*} p<0.10,{ }^{* *} p<0.05,{ }^{* * *} p<0.01$.

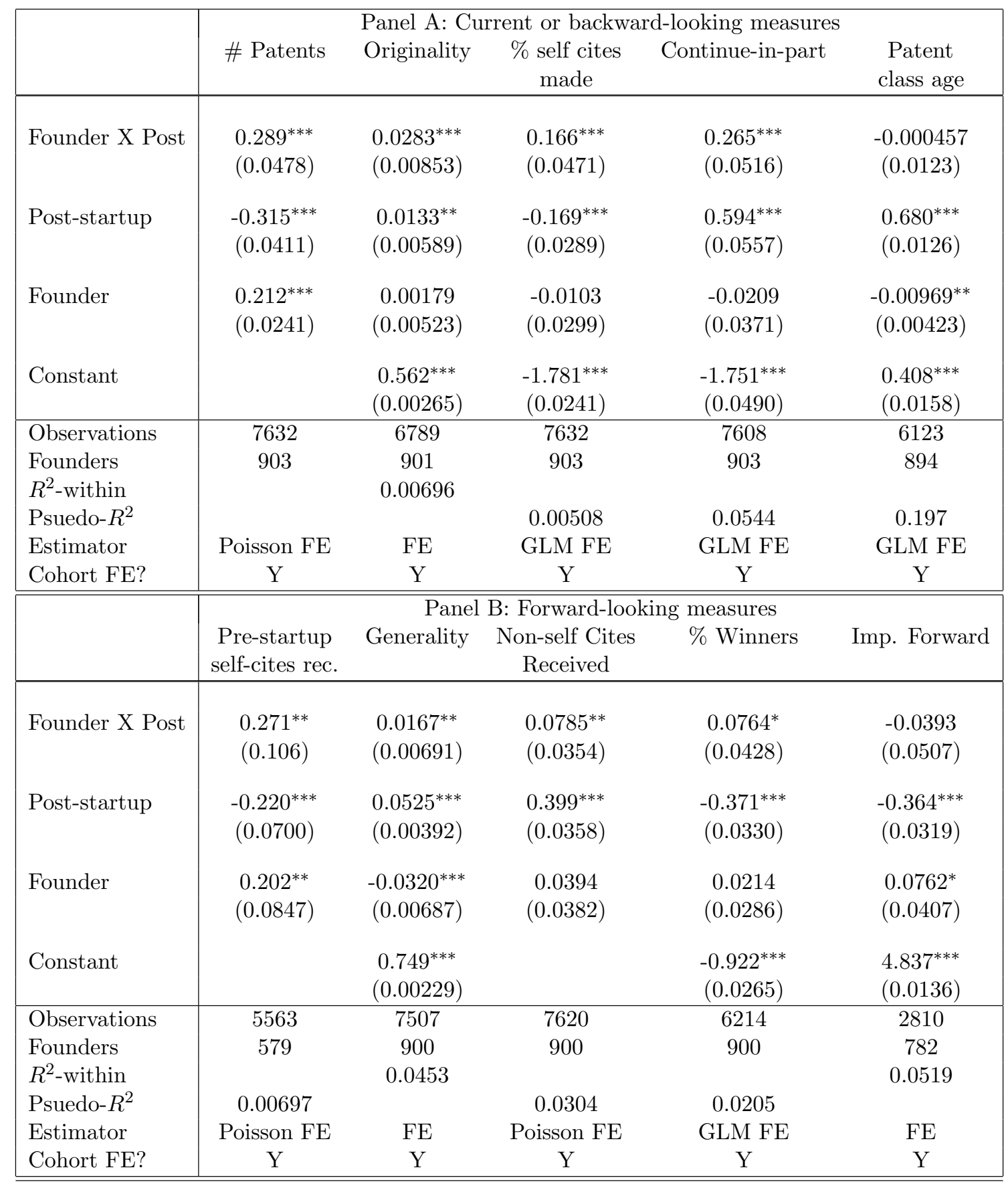


Table 9: Comparing current and backward-looking patent characteristics: No Corporate Change

Notes: Estimates from regressions with a startup founder before and after the startup event. A founder and co-inventors are excluded if the pre-founding employer had at least one "corporate change" 1 years prior to the founding. Such events are either a CEO turnover or an acquisition event. A founder is included in the sample if she has at least one patent before and after the founding. Dependent variables in Panel A focus on current or backward-looking characteristics of patents. See Table 2 for definitions. Panel B dependent variables consider forward-looking measures. For all dependent variables, the weighted means are computed in the intervals $[-4,-1]$ and $[0,5]$ using the number of patents applied in each event year. "Poisson FE" uses the fixed effects poisson regression. "FE" is the standard fixed effect regression. "GLM FE" uses the Papke and Wooldridge (2008) panel method for fractional response dependent variables. "Cohort FE?" is the fixed effect for each founder-coinventor group using the matching process described in Section 3. Variable counts and founder samples differ across columns for several reasons. Some patent lack sufficient citations to compute originality and patent class age is only available for patents applied prior to 2007. "Pre-startup self-cites rec." cohorts are excluded if there is no variation in the dependent variable (typically 0). Both the "Winners" and "Imp. Forward" require many years post-founding observations to compute, so the sample includes more recently founded firms. Standard errors clustered at the founder-co-inventor group reported in parentheses. Significance: ${ }^{*} p<0.10,{ }^{* *} p<0.05$, *** $p<0.01$.

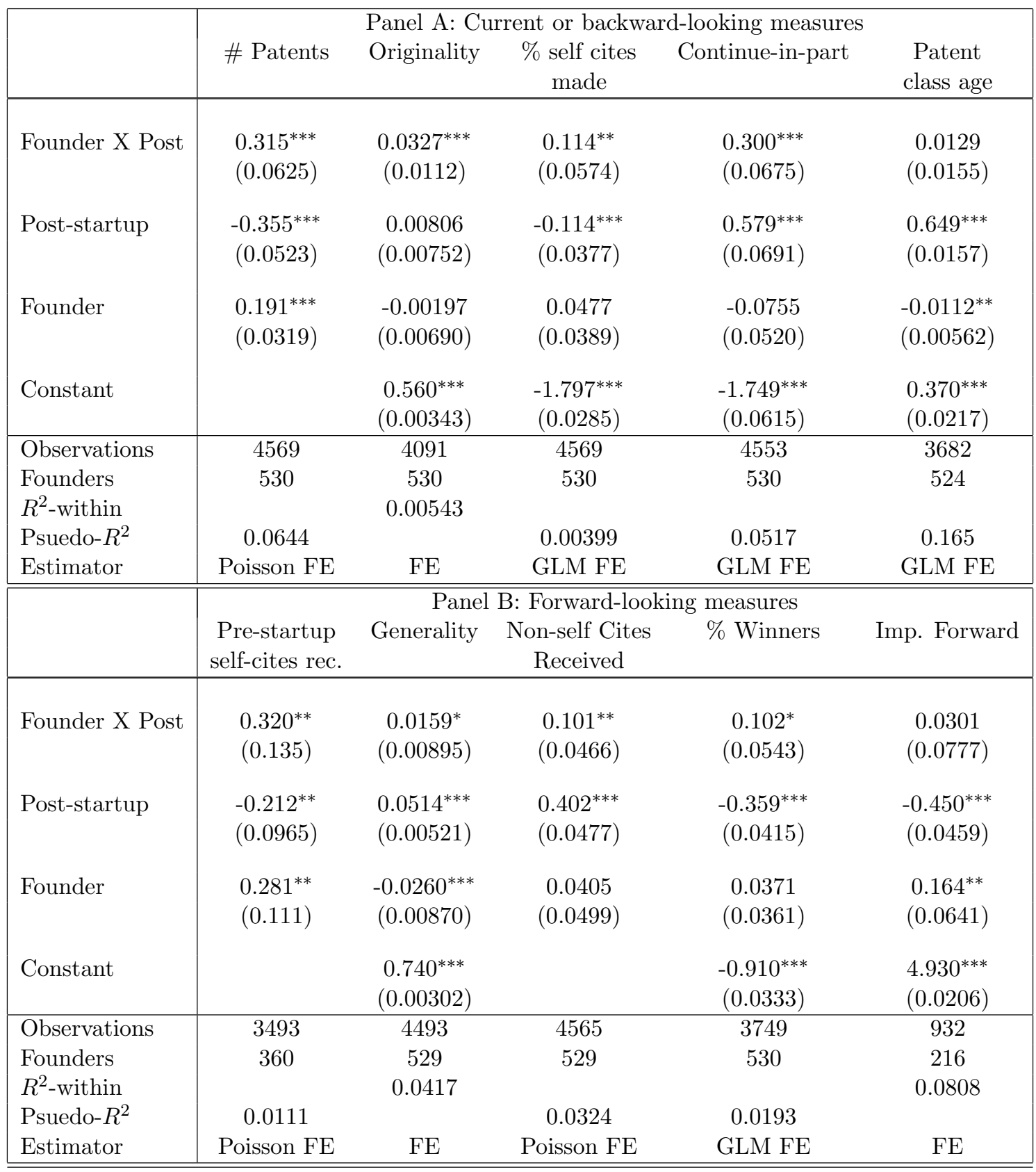


Table 10: Comparing current and backward-looking patent characteristics: Placebo

Notes: Estimates from regressions with a randomly re-assigned startup founder before and after the startup event. A founder is included in the sample if she has at least one patent before and after the startup event, which is defined as the year of the VC-backed firm's founding. A founder is included in the sample if she has at least one patent before and after the founding. Dependent variables in Panel A focus on current or backward-looking characteristics of patents. See Table 2 for definitions. Panel B dependent variables consider forward-looking measures. For all dependent variables, the weighted means are computed in the intervals $[-4,-1]$ and $[0,5]$ using the number of patents applied in each event year. "Poisson FE" uses the fixed effects poisson regression. "FE" is the standard fixed effect regression. "GLM FE" uses the Papke and Wooldridge (2008) panel method for fractional response dependent variables. "Cohort FE?" is the fixed effect for each founder-co-inventor group using the matching process described in Section 3. Variable counts and founder samples differ across columns for several reasons. Some patent lack sufficient citations to compute originality and patent class age is only available for patents applied prior to 2007. "Pre-startup self-cites rec." cohorts are excluded if there is no variation in the dependent variable (typically 0). Both the "Winners" and "Imp. Forward" require many years post-founding observations to compute, so the sample includes more recently founded firms. Standard errors clustered at the founder-co-inventor group. Significance: ${ }^{*} p<0.10,{ }^{* *} p<0.05,{ }^{* * *} p<0.01$.

\begin{tabular}{|c|c|c|c|c|c|}
\hline & \multicolumn{5}{|c|}{ Panel A: Current or backward-looking measures } \\
\hline & \# Patents & Originality & $\begin{array}{l}\% \text { self cites } \\
\text { made }\end{array}$ & Continue-in-part & $\begin{array}{c}\text { Patent } \\
\text { class age }\end{array}$ \\
\hline Founder X Post & $\begin{array}{l}-0.140 \\
(0.130)\end{array}$ & $\begin{array}{l}0.0351^{*} \\
(0.0192)\end{array}$ & $\begin{array}{r}-0.0692 \\
(0.107)\end{array}$ & $\begin{array}{r}-0.0579 \\
(0.101)\end{array}$ & $\begin{array}{l}-0.0417 \\
(0.0301)\end{array}$ \\
\hline Post-startup & $\begin{array}{c}-0.222^{* * *} \\
(0.0397)\end{array}$ & $\begin{array}{l}0.0200^{* * *} \\
(0.00563)\end{array}$ & $\begin{array}{c}-0.121^{* * *} \\
(0.0279)\end{array}$ & $\begin{array}{l}0.661^{* * *} \\
(0.0521)\end{array}$ & $\begin{array}{l}0.679^{* * *} \\
(0.0121)\end{array}$ \\
\hline Founder & $\begin{array}{c}0.0640 \\
(0.0691)\end{array}$ & $\begin{array}{c}-0.0357^{* *} \\
(0.0158)\end{array}$ & $\begin{array}{c}0.0707 \\
(0.0857)\end{array}$ & $\begin{array}{l}-0.0229 \\
(0.0780)\end{array}$ & $\begin{array}{r}-0.00135 \\
(0.0126)\end{array}$ \\
\hline Constant & & $\begin{array}{c}0.565^{* * *} \\
(0.00249)\end{array}$ & $\begin{array}{r}-1.786^{* * *} \\
(0.0248)\end{array}$ & $\begin{array}{l}-1.744^{* * *} \\
(0.0479)\end{array}$ & $\begin{array}{l}0.409^{* * *} \\
(0.0159)\end{array}$ \\
\hline \multirow[t]{2}{*}{$\begin{array}{l}\text { Observations } \\
\text { Founders } \\
R^{2} \text {-within } \\
\text { Psuedo- } R^{2} \\
\text { Estimator } \\
\end{array}$} & $\begin{array}{c}0.0493 \\
\text { Poisson FE }\end{array}$ & $\begin{array}{c}6792 \\
871 \\
0.00497 \\
\\
\text { FE }\end{array}$ & $\begin{array}{c}0.00341 \\
\text { GLM FE }\end{array}$ & $\begin{array}{l}0.0506 \\
\text { GLM FE }\end{array}$ & $\begin{array}{c}0.196 \\
\text { GLM FE }\end{array}$ \\
\hline & $\begin{array}{l}\text { Pre-startup } \\
\text { self-cites rec. }\end{array}$ & $\begin{array}{r}\text { Pane } \\
\text { Generality }\end{array}$ & $\begin{array}{c}\text { B: Forward-loo } \\
\text { Non-self Cites } \\
\text { Received } \\
\end{array}$ & $\begin{array}{l}\text { ing measures } \\
\% \text { Winners }\end{array}$ & Imp. Forward \\
\hline Founder X Post & $\begin{array}{l}0.0882 \\
(0.305)\end{array}$ & $\begin{array}{l}-0.00889 \\
(0.0123)\end{array}$ & $\begin{array}{l}-0.0644 \\
(0.0846)\end{array}$ & $\begin{array}{l}0.0861 \\
(0.150)\end{array}$ & $\begin{array}{c}0.101 \\
(0.133)\end{array}$ \\
\hline Post-startup & $\begin{array}{l}-0.144^{* *} \\
(0.0674)\end{array}$ & $\begin{array}{l}0.0565^{* * *} \\
(0.00421)\end{array}$ & $\begin{array}{l}0.423^{* * *} \\
(0.0364)\end{array}$ & $\begin{array}{c}-0.219^{* * *} \\
(0.0422)\end{array}$ & $\begin{array}{c}-0.365^{* * *} \\
(0.0253)\end{array}$ \\
\hline Founder & $\begin{array}{c}0.247 \\
(0.218)\end{array}$ & $\begin{array}{c}0.0179 \\
(0.0126)\end{array}$ & $\begin{array}{c}0.117 \\
(0.0883)\end{array}$ & $\begin{array}{l}-0.0405 \\
(0.0964)\end{array}$ & $\begin{array}{c}0.0941 \\
(0.0881)\end{array}$ \\
\hline Constant & & $\begin{array}{c}0.741^{* * *} \\
(0.00219)\end{array}$ & & $\begin{array}{r}-0.132^{* * *} \\
(0.0322)\end{array}$ & $\begin{array}{c}4.849^{* * *} \\
(0.00896)\end{array}$ \\
\hline Observations & 5601 & 7511 & 7624 & 4888 & 2810 \\
\hline Founders & 564 & 871 & 871 & 847 & 760 \\
\hline$R^{2}$-within & & 0.0402 & & & 0.0484 \\
\hline $\begin{array}{l}\text { Psuedo- } R^{2} \\
\text { Estimator }\end{array}$ & $\begin{array}{c}0.00121 \\
\text { Poisson FE }\end{array}$ & $\mathrm{FE}$ & $\begin{array}{c}0.0293 \\
\text { Poisson FE }\end{array}$ & $\begin{array}{c}0.00275 \\
\text { GLM FE }\end{array}$ & $\mathrm{FE}$ \\
\hline
\end{tabular}


Table 11: Comparing current and backward-looking patent characteristics: Superstar extinction?

Notes: Estimates from regressions with where the matched co-inventor group searches among co-inventors with the least amount of interactions with the founder in the pre-startup period. A founder is included in the sample if she has at least one patent before and after the startup event, which is defined as the year of the VC-backed firm's founding. A founder is included in the sample if she has at least one patent before and after the founding. Dependent variables in Panel A focus on current or backward-looking characteristics of patents. See Table 2 for definitions. Panel B dependent variables consider forward-looking measures. For all dependent variables, the weighted means are computed in the intervals $[-4,-1]$ and $[0,5]$ using the number of patents applied in each event year. "Poisson FE" uses the fixed effects poisson regression. "FE" is the standard fixed effect regression. "GLM FE" uses the Papke and Wooldridge (2008) panel method for fractional response dependent variables. "Cohort FE?" is the fixed effect for each founder-co-inventor group using the matching process described in Section 3. Variable counts and founder samples differ across columns for several reasons. Some patent lack sufficient citations to compute originality and patent class age is only available for patents applied prior to 2007 . "Pre-startup self-cites rec." cohorts are excluded if there is no variation in the dependent variable (typically $0)$. Both the "Winners" and "Imp. Forward" require many years post-founding observations to compute, so the sample includes more recently founded firms. Standard errors clustered at the founder-co-inventor group. Significance: ${ }^{*} p<0.10,{ }^{* *} p<0.05,{ }^{* * *} p<0.01$.

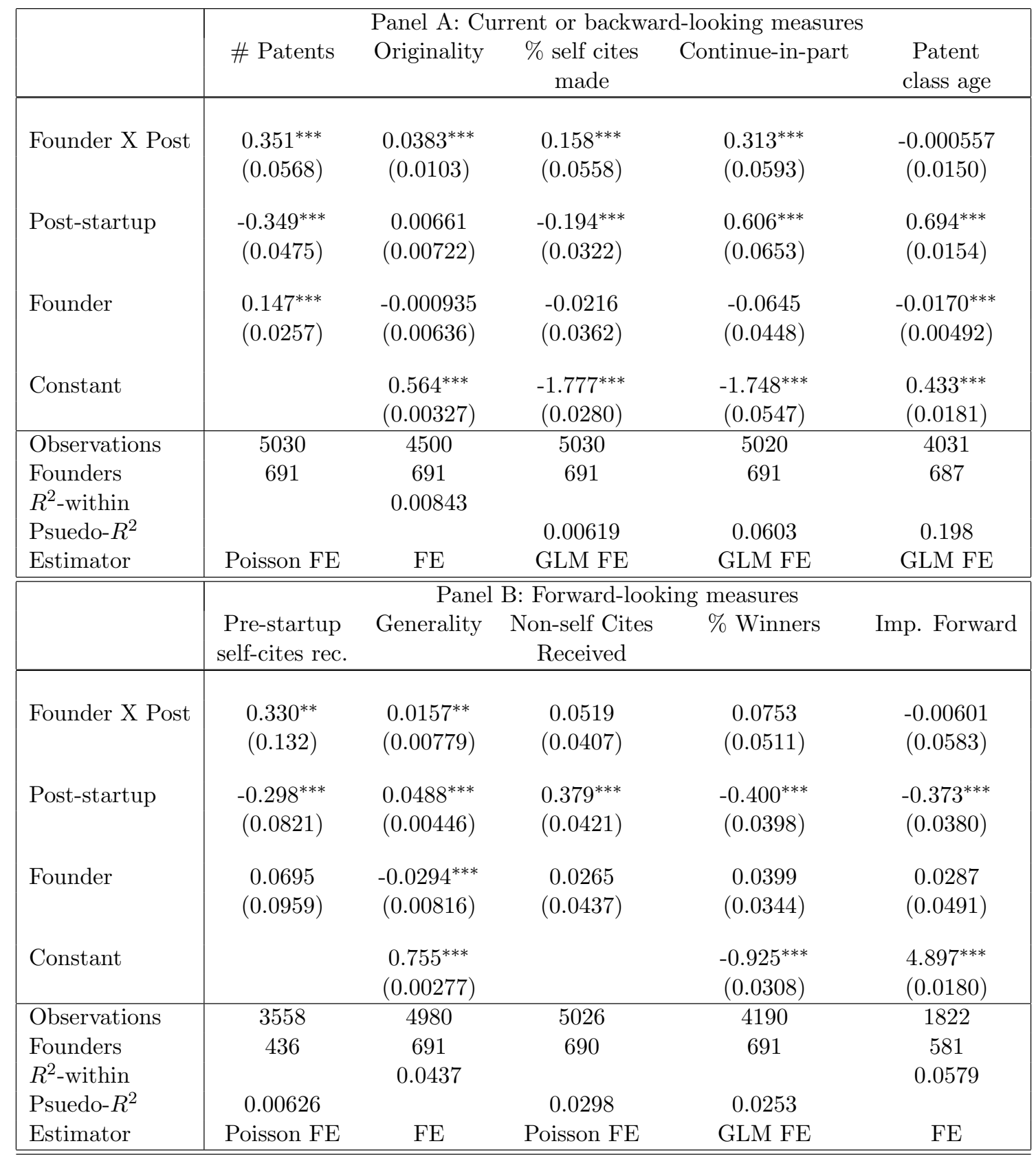


Table 12: Founders in cold-market vs. non-cold markets: pre-startup characteristics

Table reports the pre-startup differences between founders of "cold" and "hot" market startups. A hot market startup is one where the growth in the number of newly financed entrepreneurial firms is in the top quartile for the years 1988-2008, while a cold market startup in the bottom quartile of the same distribution. The remaining set of startups are in the middle $50 \%$ of the distribution. Variables are measured immediately prior to the startup founding year. Notes: Significance: ${ }^{*} p<0.10,{ }^{* *} p<0.05,{ }^{* * *} p<0.01$.

\begin{tabular}{|l|ccc|}
\hline & Cold market & Hot market & Diff./s.e. \\
\hline Total patents & 9.349 & 6.225 & $\begin{array}{c}3.124^{* *} \\
(1.018)\end{array}$ \\
Avg. Originality (adj.) & 0.563 & 0.549 & 0.0135 \\
& & & $(0.0260)$ \\
Fraction self-cites made & 0.0335 & 0.0519 & $\begin{array}{c}-0.0185 \\
(0.0111)\end{array}$ \\
Fraction patent is CIP & 0.0417 & 0.00491 & $0.0368^{* * *}$ \\
& & & $(0.0102)$ \\
Avg. age of patent class & 0.717 & 0.588 & $0.129^{* *}$ \\
& & & $(0.0165)$ \\
Pre-startup self-cites received & 0.849 & 0.775 & 0.0741 \\
& & & $(0.262)$ \\
Generality $(t=-1,4)$ & 0.738 & 0.726 & 0.0114 \\
Total non-self cites received & 107.8 & 53.28 & $(0.0281)$ \\
& & & $54.48^{* * *}$ \\
Fraction winners & 0.464 & 0.477 & -0.0132 \\
& & & $(0.0661)$ \\
Imp. forward & 4.334 & 5.161 & $-0.827^{* * *}$ \\
& & & $(0.232)$ \\
\hline Number of founders & 196 & 319 & \\
\hline
\end{tabular}


Table 13: Backward-looking measures: cold market triple difference

Notes: Estimates from regressions with where the matched co-inventor group searches among co-inventors with the least amount of interactions with the founder in the pre-startup period. A founder is included in the sample if she has at least one patent before and after the startup event, which is defined as the year of the VC-backed firm's founding. A founder is included in the sample if she has at least one patent before and after the founding. Dependent variables in Panel A focus on current or backward-looking characteristics of patents. See Table 2 for definitions. Panel B dependent variables consider forward-looking measures. For all dependent variables, the weighted means are computed in the intervals $[-4,-1]$ and $[0,5]$ using the number of patents applied in each event year. "Poisson FE" uses the fixed effects poisson regression. "FE" is the standard fixed effect regression. "GLM FE" uses the Papke and Wooldridge (2008) panel method for fractional response dependent variables. "Cohort FE?" is the fixed effect for each founder-co-inventor group using the matching process described in Section 3. Variable counts and founder samples differ across columns for several reasons. Some patent lack sufficient citations to compute originality and patent class age is only available for patents applied prior to 2007. "Pre-startup self-cites rec." cohorts are excluded if there is no variation in the dependent variable (typically 0 ). Both the "Winners" and "Imp. Forward" require many years post-founding observations to compute, so the sample includes more recently founded firms. Standard errors clustered at the founder-co-inventor group. Significance: ${ }^{*} p<0.10,{ }^{* *} p<0.05,{ }^{* * *} p<0.01$.

\begin{tabular}{|c|c|c|c|c|c|}
\hline & \multicolumn{5}{|c|}{ Current or backward-looking measures } \\
\hline & \# Patents & Originality & $\begin{array}{c}\% \text { self cites } \\
\text { made }\end{array}$ & Continue-in-part & $\begin{array}{c}\text { Patent } \\
\text { class age }\end{array}$ \\
\hline Founder X Post & $\begin{array}{l}0.276^{* * *} \\
(0.0742)\end{array}$ & $\begin{array}{c}0.0373^{* * *} \\
(0.0119)\end{array}$ & $\begin{array}{c}0.132^{* *} \\
(0.0613)\end{array}$ & $\begin{array}{l}0.304^{* * *} \\
(0.0717)\end{array}$ & $\begin{array}{c}0.00764 \\
(0.0166)\end{array}$ \\
\hline Post-startup & $\begin{array}{c}-0.345^{* * *} \\
(0.0628)\end{array}$ & $\begin{array}{c}0.00192 \\
(0.00807)\end{array}$ & $\begin{array}{c}-0.0916^{* *} \\
(0.0378)\end{array}$ & $\begin{array}{l}0.480^{* * *} \\
(0.0769)\end{array}$ & $\begin{array}{l}0.643^{* * *} \\
(0.0164)\end{array}$ \\
\hline Founder & $\begin{array}{l}0.194^{* * *} \\
(0.0376)\end{array}$ & $\begin{array}{c}-0.000323 \\
(0.00728)\end{array}$ & $\begin{array}{c}0.00898 \\
(0.0411)\end{array}$ & $\begin{array}{l}-0.0709 \\
(0.0512)\end{array}$ & $\begin{array}{l}-0.0105^{*} \\
(0.00579)\end{array}$ \\
\hline Cold market $\mathrm{x}$ Founder & $\begin{array}{c}-0.000791 \\
(0.0724)\end{array}$ & $\begin{array}{r}-0.00826 \\
(0.0141)\end{array}$ & $\begin{array}{c}0.0108 \\
(0.0921)\end{array}$ & $\begin{array}{c}-0.0592 \\
(0.110)\end{array}$ & $\begin{array}{c}0.000596 \\
(0.0121)\end{array}$ \\
\hline Cold market x Post-startup & $\begin{array}{r}-0.0548 \\
(0.112)\end{array}$ & $\begin{array}{c}0.0277 \\
(0.0175)\end{array}$ & $\begin{array}{l}-0.0799 \\
(0.0802)\end{array}$ & $\begin{array}{l}0.264^{* * *} \\
(0.0992)\end{array}$ & $\begin{array}{l}0.0664^{*} \\
(0.0351)\end{array}$ \\
\hline Cold market $\mathrm{x}$ Post $\mathrm{x}$ Founder & $\begin{array}{c}0.146 \\
(0.140)\end{array}$ & $\begin{array}{l}-0.0144 \\
(0.0230)\end{array}$ & $\begin{array}{r}-0.0332 \\
(0.128)\end{array}$ & $\begin{array}{l}0.0526 \\
(0.144)\end{array}$ & $\begin{array}{c}0.0832^{* *} \\
(0.0340)\end{array}$ \\
\hline Constant & & $\begin{array}{c}0.562^{* * *} \\
(0.00324)\end{array}$ & $\begin{array}{c}-1.787^{* * *} \\
(0.0281) \\
\end{array}$ & $\begin{array}{c}-1.694^{* * *} \\
(0.0589)\end{array}$ & $\begin{array}{l}0.412^{* * *} \\
(0.0186)\end{array}$ \\
\hline Observations & 4491 & 4743 & 5307 & 5289 & 4248 \\
\hline Founders & 516 & 648 & 650 & 650 & 641 \\
\hline $\begin{array}{l}R^{2} \text {-within } \\
\text { Psuedo- } R^{2}\end{array}$ & 0.0657 & 0.00727 & 0.00348 & 0.0522 & 0.178 \\
\hline Estimator & Poisson FE & $\mathrm{FE}$ & GLM FE & GLM FE & GLM FE \\
\hline
\end{tabular}


Table 14: Forward-looking measures: cold market triple difference

Notes: Estimates from regressions with where the matched co-inventor group searches among co-inventors with the least amount of interactions with the founder in the pre-startup period. A founder is included in the sample if she has at least one patent before and after the startup event, which is defined as the year of the VC-backed firm's founding. A founder is included in the sample if she has at least one patent before and after the founding. Dependent variables in Panel A focus on current or backward-looking characteristics of patents. See Table 2 for definitions. Panel B dependent variables consider forward-looking measures. For all dependent variables, the weighted means are computed in the intervals $[-4,-1]$ and $[0,5]$ using the number of patents applied in each event year. "Poisson FE" uses the fixed effects poisson regression. "FE" is the standard fixed effect regression. "GLM FE" uses the Papke and Wooldridge (2008) panel method for fractional response dependent variables. "Cohort FE?" is the fixed effect for each founder-co-inventor group using the matching process described in Section 3. Variable counts and founder samples differ across columns for several reasons. Some patent lack sufficient citations to compute originality and patent class age is only available for patents applied prior to 2007. "Pre-startup self-cites rec." cohorts are excluded if there is no variation in the dependent variable (typically 0 ). Both the "Winners" and "Imp. Forward" require many years post-founding observations to compute, so the sample includes more recently founded firms. Standard errors clustered at the founder-co-inventor group. Significance: ${ }^{*} p<0.10,{ }^{* *} p<0.05,{ }^{* * *} p<0.01$.

\begin{tabular}{|c|c|c|c|c|c|}
\hline & \multicolumn{5}{|c|}{ Forward-looking measures } \\
\hline & $\begin{array}{l}\text { Pre-startup } \\
\text { self-cites rec. }\end{array}$ & Generality & $\begin{array}{c}\text { Non-self Cites } \\
\text { Received }\end{array}$ & $\%$ Winners & Imp. Forward \\
\hline Founder X Post & $\begin{array}{l}0.344^{* *} \\
(0.144)\end{array}$ & $\begin{array}{l}0.0214^{* *} \\
(0.0102)\end{array}$ & $\begin{array}{c}0.0878^{*} \\
(0.0530)\end{array}$ & $\begin{array}{c}0.0669 \\
(0.0579)\end{array}$ & $\begin{array}{c}-0.0909 \\
(0.0786)\end{array}$ \\
\hline Post-startup & $\begin{array}{l}-0.182^{*} \\
(0.104)\end{array}$ & $\begin{array}{c}0.0576^{* * *} \\
(0.00570)\end{array}$ & $\begin{array}{l}0.454^{* * *} \\
(0.0550)\end{array}$ & $\begin{array}{c}-0.388^{* * *} \\
(0.0438)\end{array}$ & $\begin{array}{c}-0.297^{* * *} \\
(0.0492)\end{array}$ \\
\hline Founder & $\begin{array}{l}0.263^{* *} \\
(0.126)\end{array}$ & $\begin{array}{c}-0.0343^{* * *} \\
(0.0101)\end{array}$ & $\begin{array}{r}-0.00789 \\
(0.0577)\end{array}$ & $\begin{array}{c}0.0604 \\
(0.0382)\end{array}$ & $\begin{array}{c}0.0391 \\
(0.0639)\end{array}$ \\
\hline Cold market $\mathrm{x}$ Founder & $\begin{array}{l}0.0280 \\
(0.234)\end{array}$ & $\begin{array}{l}0.00155 \\
(0.0184)\end{array}$ & $\begin{array}{l}0.0174 \\
(0.106)\end{array}$ & $\begin{array}{l}-0.0660 \\
(0.0790)\end{array}$ & $\begin{array}{c}0.111 \\
(0.129)\end{array}$ \\
\hline Cold market x Post-startup & $\begin{array}{r}-0.0718 \\
(0.231)\end{array}$ & $\begin{array}{r}-0.00797 \\
(0.0122)\end{array}$ & $\begin{array}{c}-0.153 \\
(0.0961)\end{array}$ & $\begin{array}{l}-0.0616 \\
(0.0953)\end{array}$ & $\begin{array}{l}0.0163 \\
(0.113)\end{array}$ \\
\hline Cold market x Post x Founder & $\begin{array}{r}-0.0653 \\
(0.342)\end{array}$ & $\begin{array}{r}-0.00739 \\
(0.0195)\end{array}$ & $\begin{array}{c}0.0954 \\
(0.0988)\end{array}$ & $\begin{array}{l}0.0897 \\
(0.121)\end{array}$ & $\begin{array}{r}-0.0775 \\
(0.169)\end{array}$ \\
\hline Constant & & $\begin{array}{c}0.734^{* * *} \\
(0.00293)\end{array}$ & & $\begin{array}{c}-0.898^{* * *} \\
(0.0331)\end{array}$ & $\begin{array}{l}4.811^{\text {*** }} \\
(0.0176)\end{array}$ \\
\hline Observations & 3836 & 5202 & 5295 & 4283 & 1673 \\
\hline Founders & 411 & 647 & 647 & 647 & 459 \\
\hline$R^{2}$-within & & 0.0476 & & & 0.0377 \\
\hline Psuedo- $R^{2}$ & 0.0115 & & 0.0320 & 0.0230 & \\
\hline Estimator & Poisson FE & $\mathrm{FE}$ & Poisson FE & GLM FE & $\mathrm{FE}$ \\
\hline
\end{tabular}

